\title{
Fluid venting in the eastern Aleutian subduction zone
}

\author{
Erwin Suess, Gerhard Bohrmann, Roland von Huene, Peter Linke, \\ Klaus Wallmann, Stephan Lammers, and Heiko Sahling \\ GEOMAR, Research Center for Marine Geosciences, Kiel, Germany
}

Gisela Winckler

Institut für Umweltphysik der Universität Heidelberg, Heidelberg, Germany

Richard A. Lutz

Centre for Deep-Sea Ecology and Biotechnology, Institute of Marine and Coastal Sciences Rutgers University, New Brunswick, New Jersey

\section{Daniel Orange}

Monterey Bay Aquarium Research Institute, Moss Landing, Califomia

\begin{abstract}
Fluid venting has been observed along $800 \mathrm{~km}$ of the Alaska convergent margin. The fluid venting sites are located near the deformation front, are controlled by subsurface structures, and exhibit the characteristics of cold seeps seen in other convergent margins. The more important characteristics include (1) methane plumes in the lower water column with maxima above the seafloor which are traceable to the initial deformation ridges; (2) prolific colonies of vent biota aligned and distributed in patches controlled by fault scarps, oversteepened folds or outcrops of bedding planes; (3) calcium carbonate and barite precipitates at the surface and subsurface of vents; and (4) carbon isotope evidence from tissue and skeletal hard parts of biota, as well as from carbonate precipitates, that vents expel either methane- or sulfide-dominated fluids. A biogeochemical approach toward estimating fluid flow rates from individual vents based on oxygen flux measurements and vent fluid analysis indicates a mean value of $5.5 \pm 0.7 \mathrm{~L} \mathrm{~m}^{-2} \mathrm{~d}^{-1}$ for tectonics-induced water flow [Wallmann et al., 1997b]. A geophysical estimate of dewatering from the same area [von Huene et al., 1997] based on sediment porosity reduction shows a fluid loss of $0.02 \mathrm{~L} \mathrm{~m}^{-2} \mathrm{~d}^{-1}$ for a $5.5 \mathrm{~km}$ wide converged segment near the deformation front. Our video-guided surveys have documented vent biota across a minimum of $0.1 \%$ of the area of the convergent segment off Kodiak Island; hence an average rate of $0.006 \mathrm{~L} \mathrm{~m}^{-2} \mathrm{~d}^{-1}$ is estimated from the biogeochemical approach. The two estimates for tectonics-induced water flow from the accretionary prism are in surprisingly good agreement.
\end{abstract}

\section{Introduction}

Fluid venting along the world's subduction zones has been recognized over the past 10 years as a process of first-order importance for marine geosciences and ocean sciences [Langseth and Moore, 1990; Moore and Vrolijk, 1992 ]. Venting affects the budgets of certain elements in the deep sea [Suess and Whiticar, 1989; Martin et al., 1991, 1996], the material turnover at specialized vent ecosystems [Suess et al., 1985; Brooks et al., 1987; Rio et al., 1992; Childress et al., 1986; Boulégue et al., 1987 ] as well as the thermal structure of accretionary complexes [Le Pichon et al., 1990; Henry et al., 1992, 1996; Hyndman et al., 1993]. Fluid flow and pressure gradients may in turn influence the accretionary tectonics such as earthquake activity or multiplexing [Davis et al., 1990; Sammonds et al., 1992; Brown et al., 1994].

Copyright 1998 by the American Geophysical Union.

Paper number 97JB02131.

0148-0227/98/97JB-02131\$09.00
The circum-Pacific subduction zones manifest a variety of end-member tectonic settings, studies of which have now and in the past contributed toward an in depth understanding of the complex process at convergent margins [Kulm et al., 1986; Le Pichon et al., 1987; von Huene and Scholl, 1991, 1993; Kastner et al., 1991; Carson et al., 1994; Westbrook et al., 1995; McAdoo et al., 1996]. Critical regions for fluid escape are trenches, deformation fronts, and initial accretionary ridges. Accreted and subducted sediments are thought to be separated by interfaces with low shear strength and with concentrations of overpressured pore fluids. This interface decouples the sedimentary sequences during convergence allowing unconsolidated sediment to be subducted beneath the margin. Gradually now, the complexity of these submarine hydrogeologic processes is becoming apparent. So far there has been evidence reported for output of fresh and supersaline water from accretionary prisms [Kastner et al., 1991; Wallmann et al., 1997a] and for horizontal and vertical recirculation over considerable distances through sequences of accreted sediments [Le Pichon et al., 1990; Martin et al., 1995]. An enormous difference of flow rates, however, has been 
estimated with geophysical and geochemical methods at different convergence settings with no clear picture emerging [Carson et al., 1990; Linke et al., 1994; Henry et al., 1992, 1996].

Several orders of magnitude have separated flow estimates based on porosity reduction from those observed directly at vents. Furthermore, the question of the relative importance of focused flow as evident at vent fields versus diffuse flow without conspicuous vent communities or chimneys remains unresolved. To help clarify this situation, we report here the first comprehensive data set as well as hitherto unknown evidence for tectonically controlled, large-scale venting phenomena in the deep eastern Aleutian Trench of the Alaska subduction zone. The surveys carried out and samples collected by R/V Sonne in 1994 and 1996 compose an $800 \mathrm{~km}$ long segment between the Kodiak and Shumagin Islands. Here we found manifestations of fluid venting in the form of distinctive faunas, mineral precipitates, methane anomalies, a temperature anomaly, in situ flow data, and contrasting chemistries of pore fluids and sediments from on-vent and off-vent settings.

The temperature anomaly is small, yet significant, and documents an extra heat source to the oceanic bottom waters from below the seafloor, thus giving a new meaning to the concept of cold seeps. Overall, the significance of our discovery in the Aleutian Trench is seen in the predictability and documentation of vent sites within specific deformational settings of that accretionary margin. Our success in finding these active zones of fluid escape provides renewed confidence in being able to extrapolate and eventually to quantify tectonic dewatering within the entire global subduction framework.

\section{Geologic Setting}

The continental margin that borders the eastern Aleutian Trench has an accretionary terrane that contains lithologies as old as Late Cretaceous. The Kenai Peninsula, the Shumagin and Kodiak Islands, and presumably the shelf between them have an upper plate crust consisting of turbidites and volcanic rocks of Cretaceous to Paleogene age. The outer shelf and slope seaward of the islands are characterized by Eocene to Oligocene accreted rocks overlain by Neogene basins [Moore et al., 1991]. Sediment accreted to the continent at the trench during the current episode is generally younger than $3 \mathrm{Ma}$.

The oceanic Pacific plate that is subducted near the northeastern end of the Aleutian Trench is of Eocene age and increases in age to the southwest. The plate convergence rates are around $5.5 \mathrm{~cm} / \mathrm{yr}$ [DeMets et al., 1990]. The Aleutian Trench is generally the boundary of the North American plate, but below the eastern Gulf of Alaska the boundary is complicated by the presence of the Yakutat Block, which is currently colliding with Alaska [Bruns, 1983].

According to one plate tectonic reconstruction of the north Pacific region, the Yakutat Block resided off Washington or Oregon during the Oligocene and subsequently moved northward [Bruns, 1983]. During this transit the adjacent oceanic crust received sediment from the North American continent which was laid down in deep-sea fans [Stevenson and Embley, 1987]. Two of these fans encompass areas larger than or equal to today's Amazon Fan. The oldest, the Zodiac Fan in the west of the survey area, received hemipelagic sediment during 42 to 24 Ma but is now covered by a pelagic sediment blanket. The second oldest, the Surveyor Fan in the east of the survey area, received sediment during the period from about $20 \mathrm{Ma}$ to the present. The upper part of its clastic material is glacially derived. The youngest, the
Baranoff Fan, is located in the southeastern most part of the Gulf of Alaska and began to form in upper Miocene time. The two older fans have presumably contributed material to the accretionary prisms along the eastern Aleutian Trench; however, most of their sediment volume is currently being subducted, the process which generates the fluids being expelled at the convergent plate boundary [von Huene and Scholl, 1991].

The western part of the Yakutat Block has been subducted as shown by magnetic anomalies. Assuming it has been coupled to the Pacific plate places part of the terrane at the base of the slope, within the northeastern survey area between 3 and $5 \mathrm{Ma}$. Subsequently, its point of entry into the subduction zone swept northeastward along the trench to its present position in the northern Gulf of Alaska. Thus the tectonic history of the accretionary domains in our survey area includes a former collisional segment currently in an area receiving high amounts of interglacial sediment, a noncollisional segment receiving Surveyor Fan and trench sediment loaded with glacial debris, and a segment where the head of the Eocene Zodiac Fan and the older oceanic crust have entered the subduction zone. In the western survey area the thickness of trench sediments is significantly less than in the eastern area.

Four segments of the margin were investigated during $\mathrm{R} / \mathrm{V}$ Sonne cruises (Figure 1, SO-96, SO-97, and SO-110 [Flüh and von Huene, 1994; Suess, 1994; Suess and Bohrmann, 1997]. All stations occupied and surveys conducted during these cruises and referred to in this communication are listed in Table 1. Extensive seismic reflection data [von Huene et al., 1987; von Huene, 1989] were merged with the high-resolution swath bathymetry obtained during the R/V Sonne cruises to locate the accretionary ridges which became the focus of our bottom surveys, sampling, and fluid monitoring.

The Edge sector includes an accretionary mass that was probably built against the erosional scar formed during collision of the Yakutat Block. Here the trench axis receives a large amount of terrigenous glacial sediment from the adjacent Alaskan mainland capped by an interglacial sequence (Deep Sea Drilling Project Site 180) [Kulm and von Huene, 1973]. In the Edge sector the youngest tectonic structures, forming the deformation front, consist of two relatively gentle folds with their asymmetric oversteepened flanks facing the trench (Figure 2). These structures are parallel to and situated just at the deformation front in about 5000 $\mathrm{m}$ of water depth. Toward the southwest they terminate against a steep scar, believed to be the lateral strike-slip fault of a subducted seamount trace. The folds expose trench fill sediments; their relief reaches about $300 \mathrm{~m}$ above the trench floor; and their steepened flanks exhibit many slumps visible in the high-resolution swathmapping (Figure 2). The escarpments expose gently landward dipping strata. At the base of these escarpments, but also higher up at intermediate steps in the morphology, we found colonies of vent biota and other manifestations of fluid escape.

In the Albatross sector the deformation front consists of a growing anticlinal fold on the $5000 \mathrm{~m}$ deep trench axial floor with a relief of up to $400 \mathrm{~m}$. Sediment in the trench is probably distal glacial material channeled from southern Kodiak Island by a welldefined glacial trough extending from the island to the upper slope above the surveyed sector. Where it is crossed by seismic lines, the structure includes blind backthrusts with a landward verging fold [von Huene, 1989; von Huene et al., 1997]. The steeper slope facing the trench is also sculpted by slumps, but generally, they are not as numerous or as extensively developed as those in the Edge sector. The failed slopes expose strata horizontal in the strike direction along which fluids escape, apparently rapidly enough to support the vent colonies observed here. 


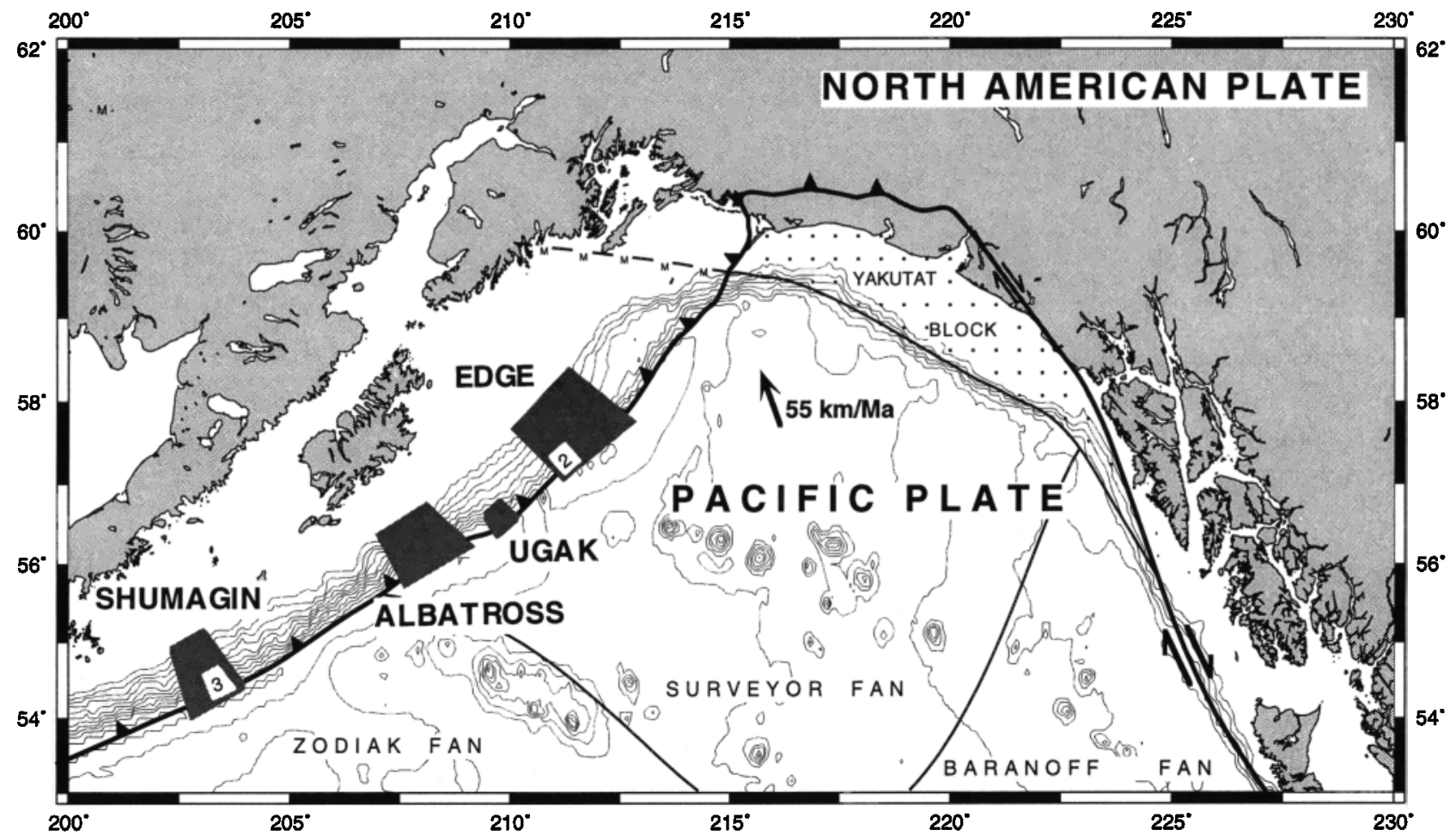

Figure 1. Gulf of Alaska with major plate boundaries, fan deposits and the areas of investigation during R/V Sonne cruises SO-96, SO-97 and SO-110. The areas are referred to in the text as the Edge, Albatross, Shumagin, and the Ugak sectors; white squares show surveys in Edge (Figure 2) and Shumagin sectors (Figure 3).

The Shumagin sector, where the trench axis is $6000 \mathrm{~m}$ deep, receives much of its axial fill by lateral transport from the northeast. The folds at the deformation front show little evidence of slumping and are discontinuous along strike. Owing to the more oblique subduction in this part of the survey area, the lateral component on convergence becomes larger than to the northeast and hence a pattern of shear faults develops diagonal to the axial trend [Lewis et al, 1988]. Little evidence for venting was found along the folds at the deformation front; instead, more active vents and extensive carbonate crusts were observed along the crestal regions of ridges farther upslope, where they were cut by canyons (Figure 3). The vent biota colonies were similar to those in the Edge and Albatross sectors.

In the Ugak sector, located about half way between Edge and Albatross and within the area receiving Surveyor Fan sediments, the seaward flanks of the first three anticlinal ridges were investigated. Vent biota were found along the seaward face of the third ridge and the summit of the first ridge. A large clam field, about $40 \mathrm{~m}$ across, was found at $4880 \mathrm{~m}$ near the rugged seaward facing flank of the third ridge. This area was dominated by scarps (2-6 m high) and outcrops of landward dipping strata. The first ridge, of relatively smooth morphology, showed a large clam field right at the top $(5000 \mathrm{~m})$. Evidence for fluid venting was not discovered along the second ridge; however, only one crossing with the towed TV system was carried out, and no distinct structural features could be associated with the active vents. Nevertheless, the discoveries at Ugak confirmed that fluids are expelled along the entire length of the convergence zone surveyed.

\section{Finding and Characterizing Active Vent Sites}

Locating vents at subduction zones without direct observations from submersibles or remotely operated vehicles (ROVs) is difficult. There is a great disparity in space scales between what can be identified geophysically as a deformation front or the likely projection to the seafloor of possible fluid pathways such as faults and the much smaller dimensions of actual vents. In seismic sections, faults are of the order of many hundreds of meters long or folds have hundreds of meters of relief, but active vent sites cover only a few square meters; perhaps aligned vents are a few hundred meters long. At $5000 \mathrm{~m}$ depth, hydrosweep soundings are in a $50 \times 500 \mathrm{~m}$ grid, and seismic traces are $50 \mathrm{~m}$ apart. Bathymetric depth resolution is $20-30 \mathrm{~m}$ at best, seismic resolution $40-60 \mathrm{~m}$ at best. The width of the TV survey vision is about $12 \mathrm{~m}$. It might take four to five transects to completely image a potential vent site in seismic records or bathymetry. We have searched for active vent areas by mapping anomalies of dissolved methane in the near-bottom water column and by conducting video surveys. Chemical anomaly mapping detects vents which emit methane assuming that the background $\mathrm{CH}_{4}$ content and other nonvent sources of $\mathrm{CH}_{4}$ are known [Lammers et al., 1995]. Furthermore, it assumes that $\mathrm{CH}_{4}$ and other reduced chemical species, dominantly $\mathrm{H}_{2} \mathrm{~S}$, maintain colonies of characteristic vent biota as well as create the environment conducive to precipitation of crusts, concretions, or chimneys.

During the search for vents in the three sectors off Alaska, we used a combination of TV surveys, near-bottom temperature recordings, and methane monitoring of the lower water column. The TV sled EXPLOS (Ocean Floor Exploration System) aboard $\mathrm{R} / \mathrm{V}$ Sonne is equipped with a black-and-white Osprey video camera, two Photosea still cameras, three halogen lamps, and a conductivity-temperature-depth (CTD) System (SIS 6000). All data and images are continuously displayed in real time aboard the vessel. The system is navigated with a Super-Short-Baseline (SSBL HPR-1507) by Simrad and a responder mounted to the sled. The instrument is towed at approximately 0.5 to $1 \mathrm{knot}$, 
Table 1. List of Stations Surveyed in the Eastern Aleutian Subduction Zone During R/V Sonne Cruises SO-96, SO-97, and SO-110

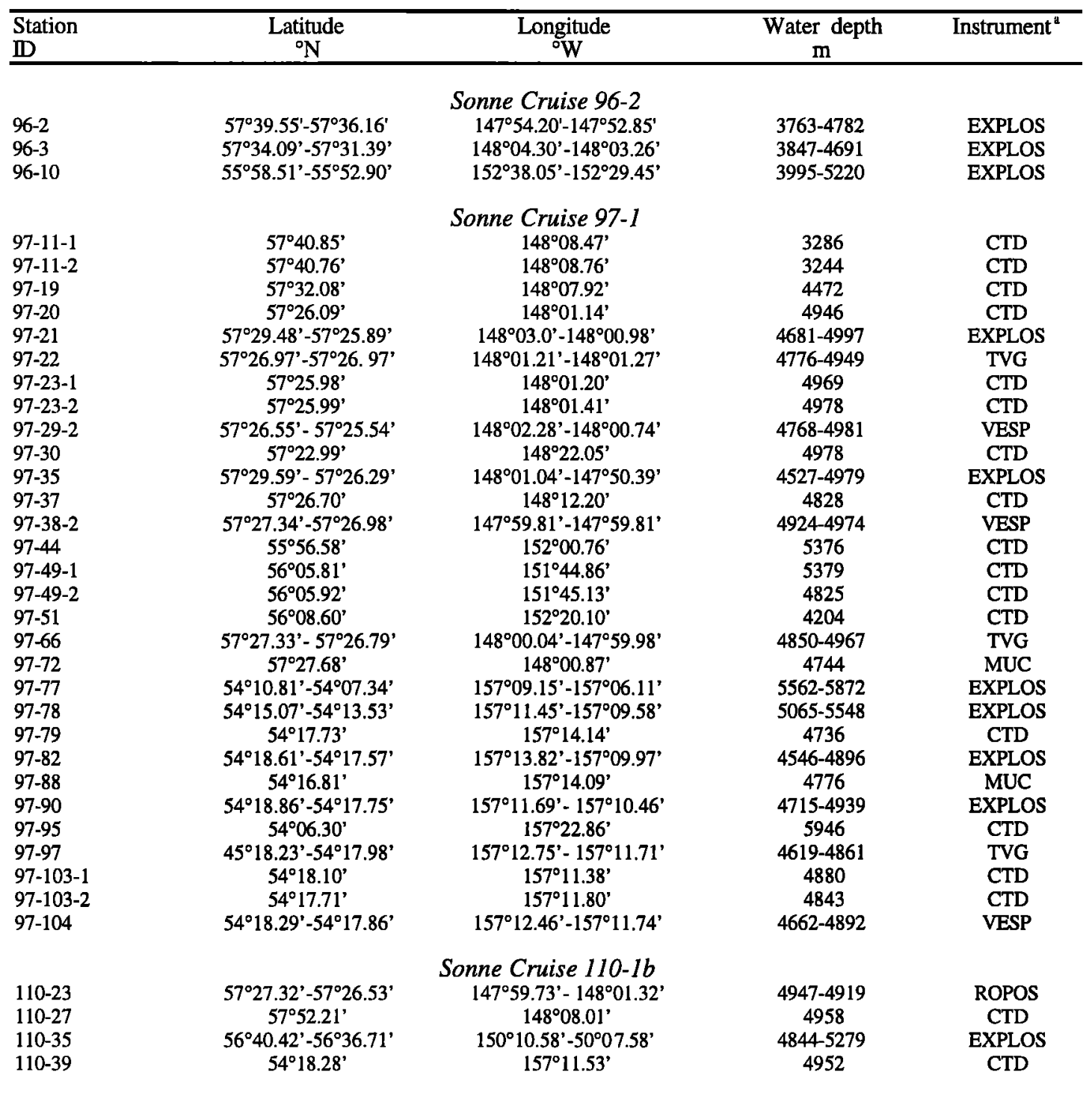

"CTD, standard CTD with rosette; EXPLOS, towed video-guided survey system; TVG, video-guided grab sampler; VESP, video-guided vent sampler with benthic chamber; MUC, multicorer; and ROPOS, remotely operated vehicle

preferably downslope. The height of 1-6 m above the bottom is maintained by an operator continually adjusting the length of winch cable. The sled-mounted CTD records any temperature anomalies. Additionally, hydrocasts with conventional CTD and rosette sampler obtained water samples for $\mathrm{CH}_{4}$ determinations at discrete and closely spaced depth intervals [Suess, 1994; Suess and Bohrmann, 1997].

Multibeam bathymetry, processed and displayed by the Hydro Map System (HMS 300) on board R/V Sonne provided updated background information for siting of the near-bottom hydrocasts as well as the TV sled transect and, where appropriate, for deployment of a TV-guided grab and vent fluid sampler (VESP). The depth range of individual TV surveys, each with 3-4 hours of bottom time, covered up to $1000 \mathrm{~m}$ vertically and of the order of $10 \mathrm{~km}$ horizontally, depending on the bottom morphology. Successive tracks were used to provide a composite depth transect. For the Edge sector, a total of 13 surveys were conducted which covered the Neogene accretionary prism at depths from 2500 to
$4900 \mathrm{~m}$. Of these surveys four are referred to here in more detail (stations 96-2, 96-3, 97-21, and 97-35). Four surveys were located in the Albatross sector, and data from one of these are used here (station 96-10). Seven surveys were run in the Shumagin sector, four of which are dealt with here in more detail (stations 97-77, $97-78,97-80,97-82)$. One survey was run in the Ugak sector (station 110-35). Extensive venting was shown at Edge and Albatross at only the first and second deformation ridges, at Shumagin at the third ridge upslope, and at Ugak at the third and the first ridges. Here we document and discuss the accumulated evidence for fluid expulsion based on four criteria: $\mathrm{CH}_{4}$ anomaly, potential temperature anomaly, benthic colonies, and inorganic chemical precipitates. Then we consider estimates of flow rates and show that bioirrigation is a major component of flow emitted at the seafloor and that true tectonics-induced flow is more than an order of magnitude smaller, though it agrees well with independent estimates based on a geophysical approach. 


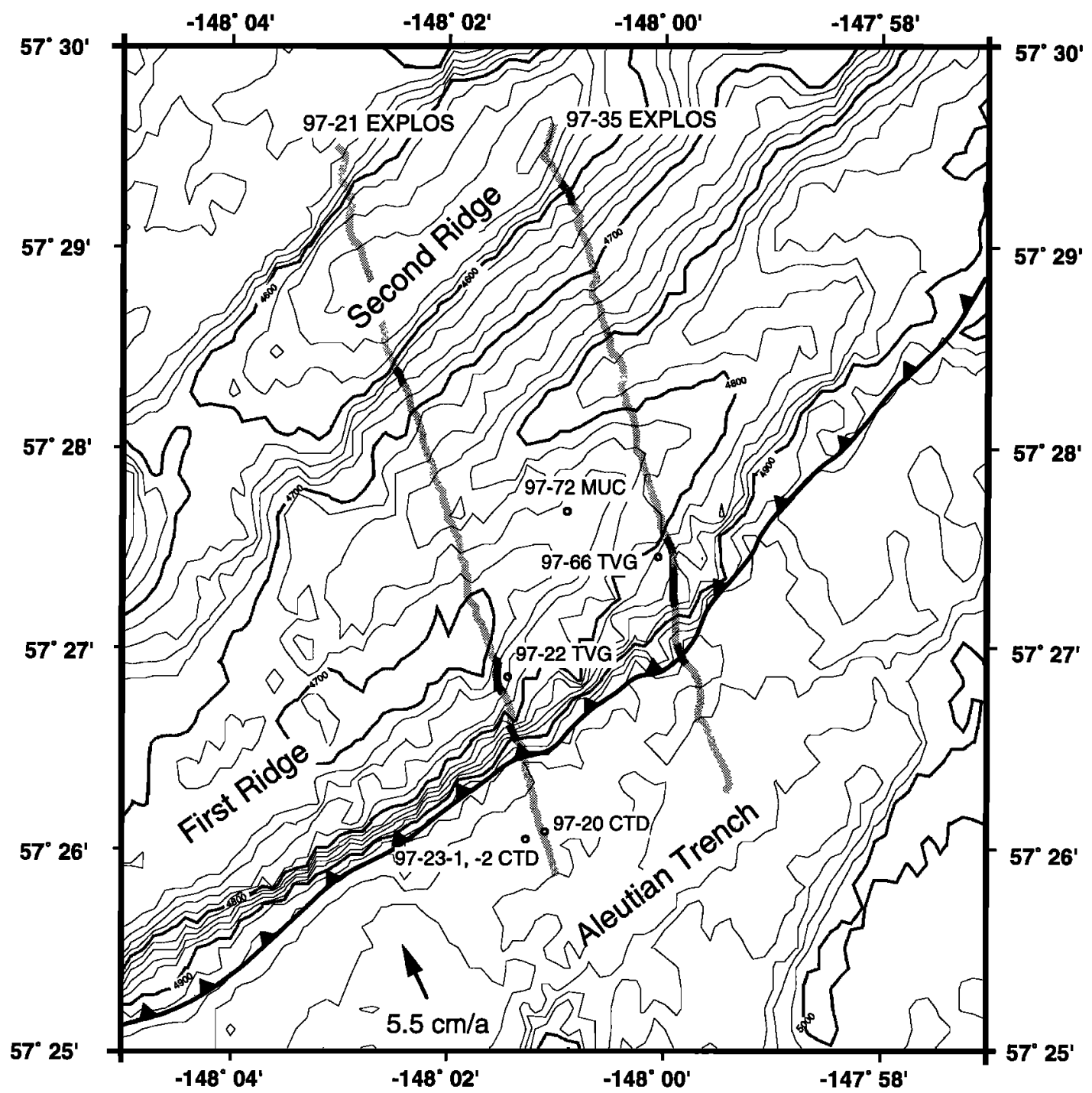

Figure 2. Location map of the vent sites from the Edge sector with $20 \mathrm{~m}$ depth contours. The bold segments along the tracks of the surveys (stations 97-21, and 97-35) by the Ocean Floor Exploration System (EXPLOS) indicate active venting. CTD stations 97-23-1 and 97-23-2 show methane anomalies; coring stations 97-66 (TVguided box corer, TVG) and 97-72 (multicorer, MUC), from which pore waters were extracted, represent on-vent and off-vent sites, respectively. The outline of the survey does not correspond in detail to the area of investigation shown in Figure 1.

\subsection{Methane}

The methane distribution in the water column shows a nearsurface maximum with decreasing concentrations, including some fine structure, over the approximate depth interval of the oxygen minimum zone. This pattern reflects production of methane during zooplankton grazing and biogeochemical cycling during particle decomposition [de Angelis and Lee, 1994; Tilbrook and Karl, 1995]. Below about $1000 \mathrm{~m}$ the $\mathrm{CH}_{4}$ contents stay close to the detection limit and remain low throughout the deeper water column [Scranton and Brewer, 1978; Tilbrook and Karl, 1995]. This relatively simple pattern is well known and documented in all casts over the Aleutian Trench (Figures 4a-4d). However, additional $\mathrm{CH}_{4}$ input from cold seeps provides a strong signal for locating dewatering and degassing sites in subduction zones. $\mathrm{CH}_{4}$ monitoring of the near-bottom water column at the Edge, Albatross, and Shumagin sectors yielded repeated and consistent anomaly patterns from which to deduce active venting and to launch TV surveys and subsequent sampling of small-scale targets. Frequently, we found evidence for a plume-shaped $\mathrm{CH}_{4}$ distribution in the lower water column with methane injection presumed to be lateral at some short distance away from the cast. The plume pattern is best illustrated by data from an array of hydrocasts in the Edge sector (Figures $4 \mathrm{a}$ and $4 \mathrm{~b}$ ). A downslope profile of four CTD casts shows oceanic $\mathrm{CH}_{4}$ background to about $3000 \mathrm{~m}$. Between $3000 \mathrm{~m}$ and the seafloor, just off the third deformation ridge, a well-developed plume was observed (stations 97-11-1 and 97-11-2 ). Farther downslope at station 97-19, no $\mathrm{CH}_{4}$ input was detected, but $\mathrm{CH}_{4}$ contents increased dramatically toward the scar of a subducted seamount (stations 97-30 and 9737). Within the embayment formed by the collision of the seamount with the margin, the highest $\mathrm{CH}_{4}$ contents anywhere over the entire Aleutian Trench were detected. Unfortunately, not enough time was available during the R/V Sonne cruises to inspect this area more closely with video surveys or to conduct highresolution sampling for methane. From the magnitude of the 


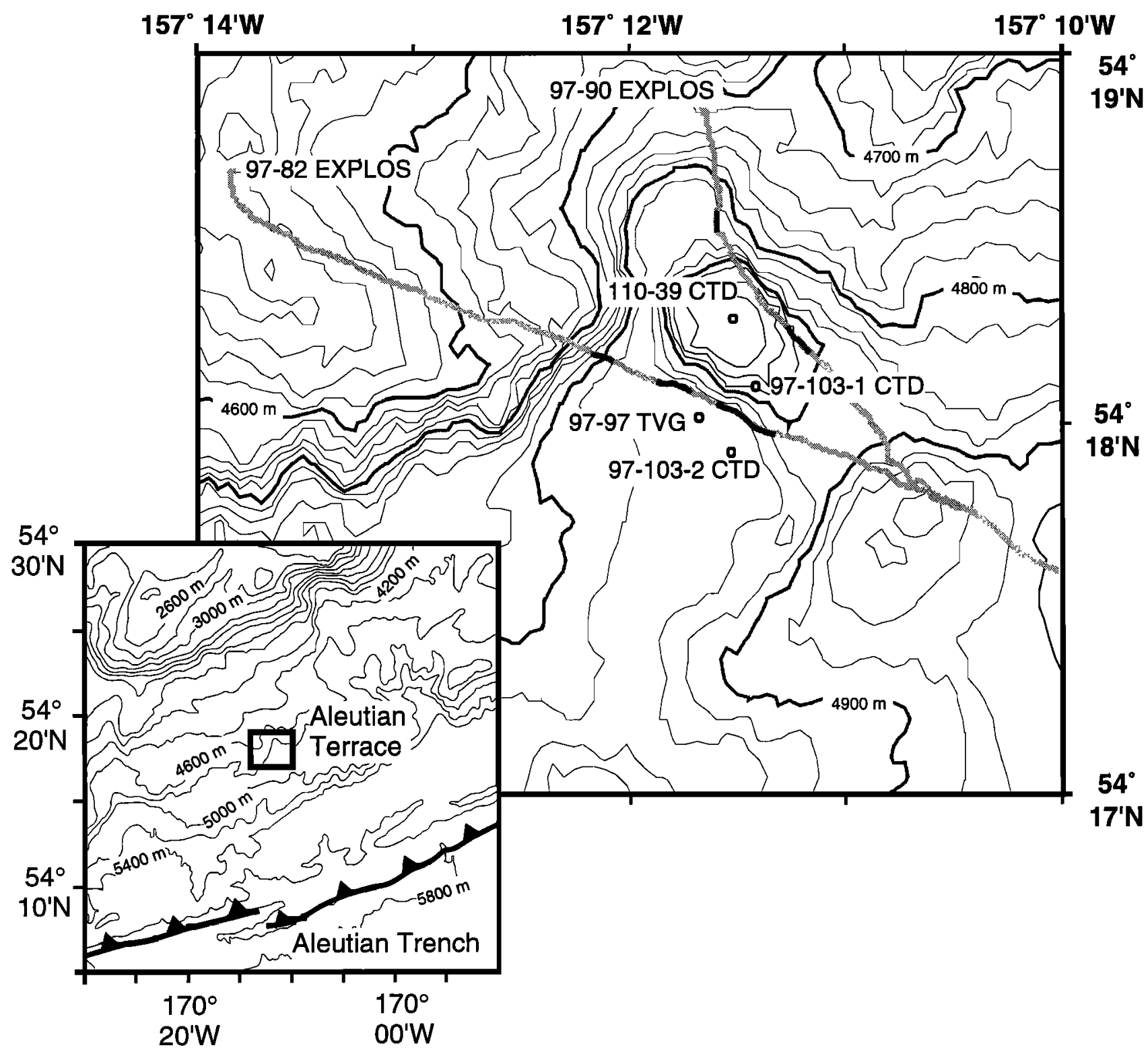

Figure 3. Location map of the vent sites from the Shumagin sector with $2 \mathrm{~m}$ depth contours. The bold segments along the EXPLOS tracks (stations 97-82, and 97-90) indicate active venting. CTD stations 97-103-1, 97-103-2, and 110-39 show methane anomalies and the coring station 97-97 (TV-guided box corer, TVG) yielded carbonate precipitates. The survey is located on the Aleutian Terrace (inset); the map outlines do not correspond in detail to the area of investigation shown in Figure 1.

anomaly, we would expect a $\mathrm{CH}_{4}$ source of considerable strength somewhere very near by. Repeated CTD casts over the trench, just seaward of the initial deformation ridges, also showed a welldefined, near-bottom $\mathrm{CH}_{4}$ maximum (Figure 4b, stations 97-20, 97-23-1, and 97-23-2). The same plume was found again 2 years later during the recently completed cruise SO-110 (station 11027), although the concentration was somewhat diminished.

Generally, the $\mathrm{CH}_{4}$ plumes are confined to the lower water column. The anomalies of between 50 and $150 \mathrm{~nL} / \mathrm{L}$ are not quite as high as those at mid-ocean ridges [Horibe et al., 1986; Lilley et al., 1993]; however, they are significantly higher than the oceanic background. A characteristic feature appears to be that the lowermost sample immediately above the bottom usually contains less $\mathrm{CH}_{4}$ than the samples higher up. This probably indicates that the source is not directly below the cast but somewhere to the side, or as has been recently postulated, it might signify short-term pulses of vertical $\mathrm{CH}_{4}$ injection followed by mixing [Radlinski and Leyk, 1995]. The slopeward projection of the maximum $\mathrm{CH}_{4}$ value (Figure 4b) coincides with the ridge crest depths, where chemosynthetic communities indicate venting.

In the Albatross sector, three casts, two at the lower slope (stations 97-44, 97-49-1, and 97-49-2) and the other on the mid slope (station 97-51), showed positive $\mathrm{CH}_{4}$ anomalies (Figure $4 \mathrm{c}$ ). The site of the $\mathrm{CH}_{4}$ anomaly at the deepest location, although rather weak, is populated by prolific bivalve colonies at the trench-facing flank of a growing anticlinal fold. Again, this observation is clear evidence for structurally controlled dewatering. The $\mathrm{CH}_{4}$ pattern found at the mid slope station, with the maximum concentration immediately above the bottom, suggests venting quite close by. This potential vent site was also not investigated further at the time.

In the Shumagin sector three hydrocasts covered the entire margin horizontally and vertically from the trench floor to the upper slope off the backstop ridge (stations 97-79, 97-95, and 97- 

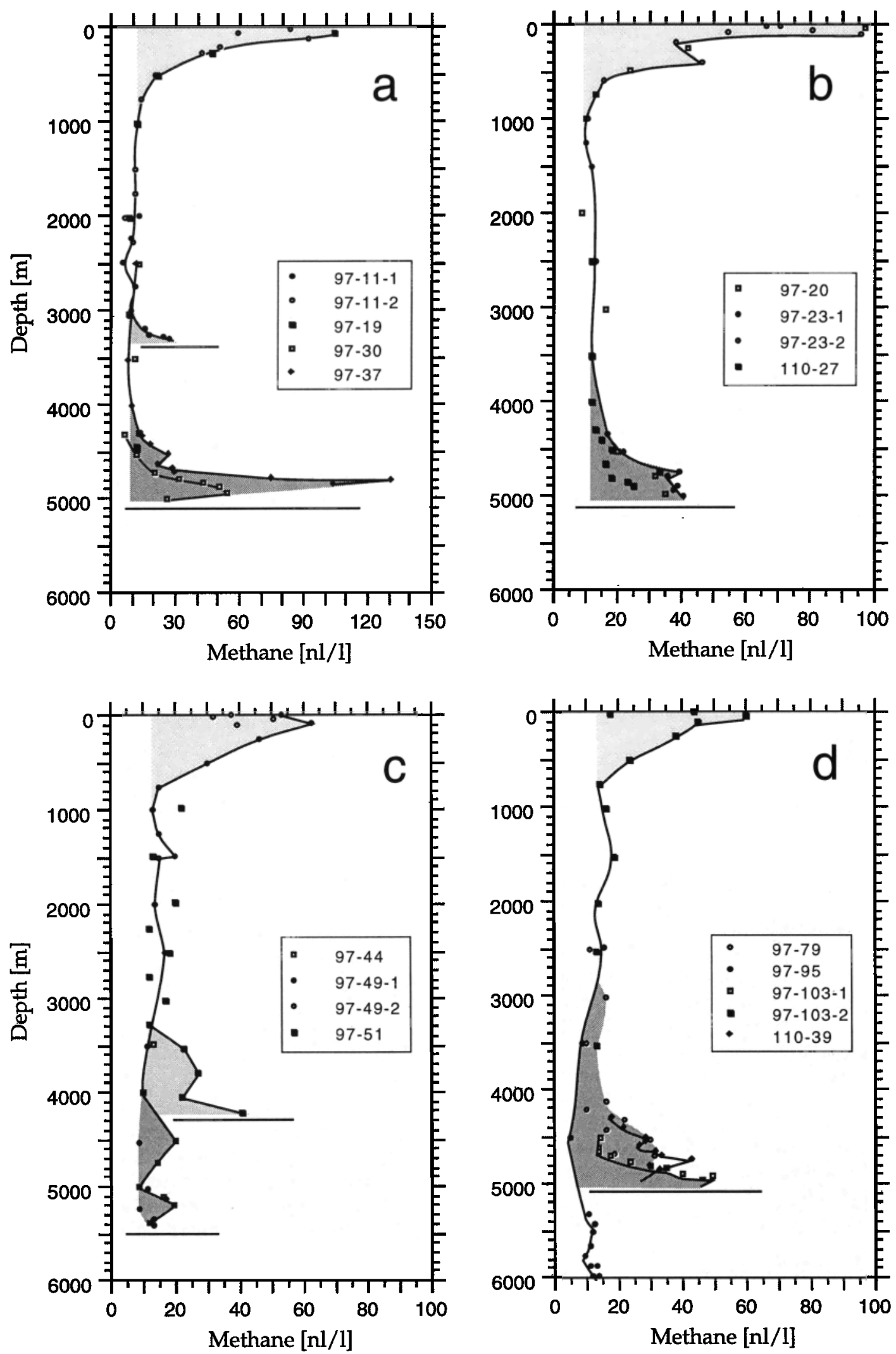

Figure 4. Methane distribution in the oceanic water column over the Aleutian Trench. Injection of $\mathrm{CH}_{4}$ from the seafloor at the Edge sector; (a) stations 97-11-1, 97-11-2, 97-19, 97-30, 97-37, (b) stations 97-20, 97-23-1, 97-232, and 110-27, Albatross sector; (c) stations 97-44, 97-49-1, 97-49-2, and 97-51, and Shumagin sector; (d) stations 97-79, 97-95, 97-103-1, 97-103-2, and 110-39. Bottom depth is indicated by horizontal lines; note welldeveloped plumes at different depths off the bottom which correspond to deformation ridges; also note different concentration scale for Figure 4a. The maxima of $\mathrm{CH}_{4}$ in surface waters and decreasing gas contents to about 800 $\mathrm{m}$ depth are due to biogeochemical cycling. 
103). The depths of the lower water column thus surveyed ranged from 3000 to $6000 \mathrm{~m}$. Such coverage over a distance of more than $50 \mathrm{~km}$ is not detailed enough to locate all possible venting structures, yet the deformation ridge at lower slope, between 4300 and $4900 \mathrm{~m}$, showed significant $\mathrm{CH}_{4}$ anomalies in two casts (Figure 4d, stations 97-79, and 97-103). This location, inside a canyon which crosscuts the third accretionary ridge, was confirmed to be an active vent site by EXPLOS-surveys and TVG sampling. The $\mathrm{CH}_{4}$ anomaly was located again 2 years later (station 110-39), generally coinciding with the previous maximum. Surprisingly, the water column at the trench axis near the deformation front showed no $\mathrm{CH}_{4}$ anomaly (station 97-95). Again, a high-resolution survey would most likely ascertain more widespread and significant $\mathrm{CH}_{4}$ injection than currently documented in the Shumagin sector.

\subsection{Temperature}

No clear evidence for positive temperature anomalies in the bottom water surrounding subduction vents had been reported, although elevated heat flow has generally been associated with vent colonies [Henry et al., 1992] and high sediment temperatures, for example, in excess of $20^{\circ} \mathrm{C}$, were recorded on a mud volcano site off Barbados [Henry et al., 1996]. Here in the Edge sector near the deformation ridges as well as at several other locations across the Alaska margin, the EXPLOS-mounted CTD sensors showed, for the first time, evidence for a slight temperature anomaly in the water column. Figure 5 shows composite potential temperature versus depth records obtained from five TV surveys while towing the instrument over the deformation ridges (stations 96-2, 96-3, 96-10, 97-35, 97-77, and 97-78). During this largely horizontal trajectory the instrument continually traverses different in situ temperature regimes as a function of adiabatic heating, which makes it difficult to identify true anomalies. Potential temperature, however, compensates for the adiabatic heating and allows identification of an extra heat source. The composite temperature record from one TV survey at station 97-35 deviates significantly from those of all other surveys which cover the same depth range but were located off vent (Figure 5). There is a small positive temperature anomaly $\left(+0.010 \pm 0.002^{\circ} \mathrm{C}\right)$ for the entire record at station 97-35. Furthermore the crestal regions of each ridge show maxima in temperature. Both ridges show venting at their trench-facing flanks. It is clear that the reproducibility, based on repeated deployment of the instrument, and our lack of exact knowledge about the regional temperature structure of the water mass in the Aleutian Trench and, particularly, the amplitude of internal waves make it difficult to unambiguously prove the temperature anomaly. Nevertheless, we are confident that future high-accuracy data will confirm heat input from vents along the entire subduction zone.

\subsection{Fauna}

The second and by far the most characteristic indicator for active venting is the occurrence of seep biota. These consisted of bacterial mats, pogonophorans, vestimentiferan and omnipresent large colonies of bivalves. At all four sectors, abundant colonies of vesicomyid clams, solemyid protobranchs, perivate pogonophorans, and new, unusual vestimentiferans were observed and sampled (Plates 1 and 2). During R/V Sonne cruise 110 the collection of specimens was considerably enlarged. The work on taxonomy of the organisms has not been completed but will be dealt with in subsequent papers. Nevertheless, it appears that most

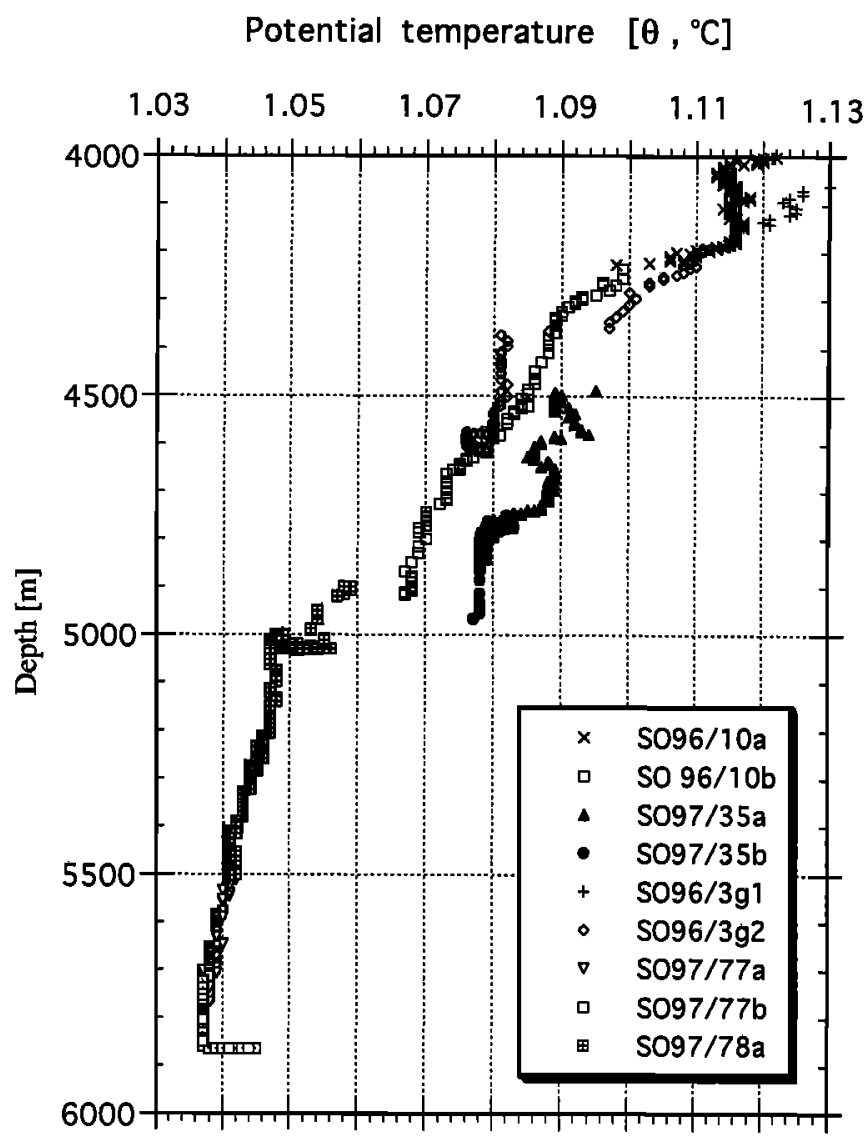

Figure 5. Composite profile of potential temperature versus depth from CTD deployments along five EXPLOS tracks. Stations 96-2, 96-3, 96-10, 97-77, and 97-78 show ambient distribution; station 97-35 shows a positive temperature anomaly throughout the survey as recorded over initial deformation ridges with active venting.

of the organisms are closely related to those found previously at other subduction vents and cold seeps.

Numerous species of vesicomyid clams have previously been found at cold seeps off Oregon, Japan, and Peru and at the Monterey and Ascension Fan Valleys off California [Hashimoto et al., 1989; Olu et al., 1996; Barry et al., 1996; Embley et al., 1990; Rau et al., 1990; Suess et al., 1985]. Their nutrition is based on thiotrophic chemoautotrophy, as indicated by light $\delta^{13} \mathrm{C}$ values [Rau et al., 1990], enzymatic and ultrastructural work [FialaMédioni et al., 1993], and anatomical characteristics [FialaMédioni and Le Pennec, 1989]. Several species of solemyids have been encountered in sewage outfalls and other highly reduced sediments and cold seeps in the deep sea [Felbeck et al., 1981; Suess et al., 1985; Embley et al., 1990; Paull et al., 1984]. Their nutrition is also based on thiotrophy of the endosymbionts. Because of the large individual size of the bivalves, their light coloration, their great abundance and characteristic arrangements in clusters and alignments, they are ideally suited for visual detection of active vent sites. Vestimentiferans and pogonophorans are also chemoautotrophic, although their nutritional pathway and sources are not fully known. Most species are thiotrophic; some are clearly menthanotrophic [Brooks et al., 1987; Southward et al., 1986, 1981; Schmaljohann et al., 1990].

Our most extensive survey for vent fauna was along strike of the two deformation ridges of the Edge sector. Two crossings 

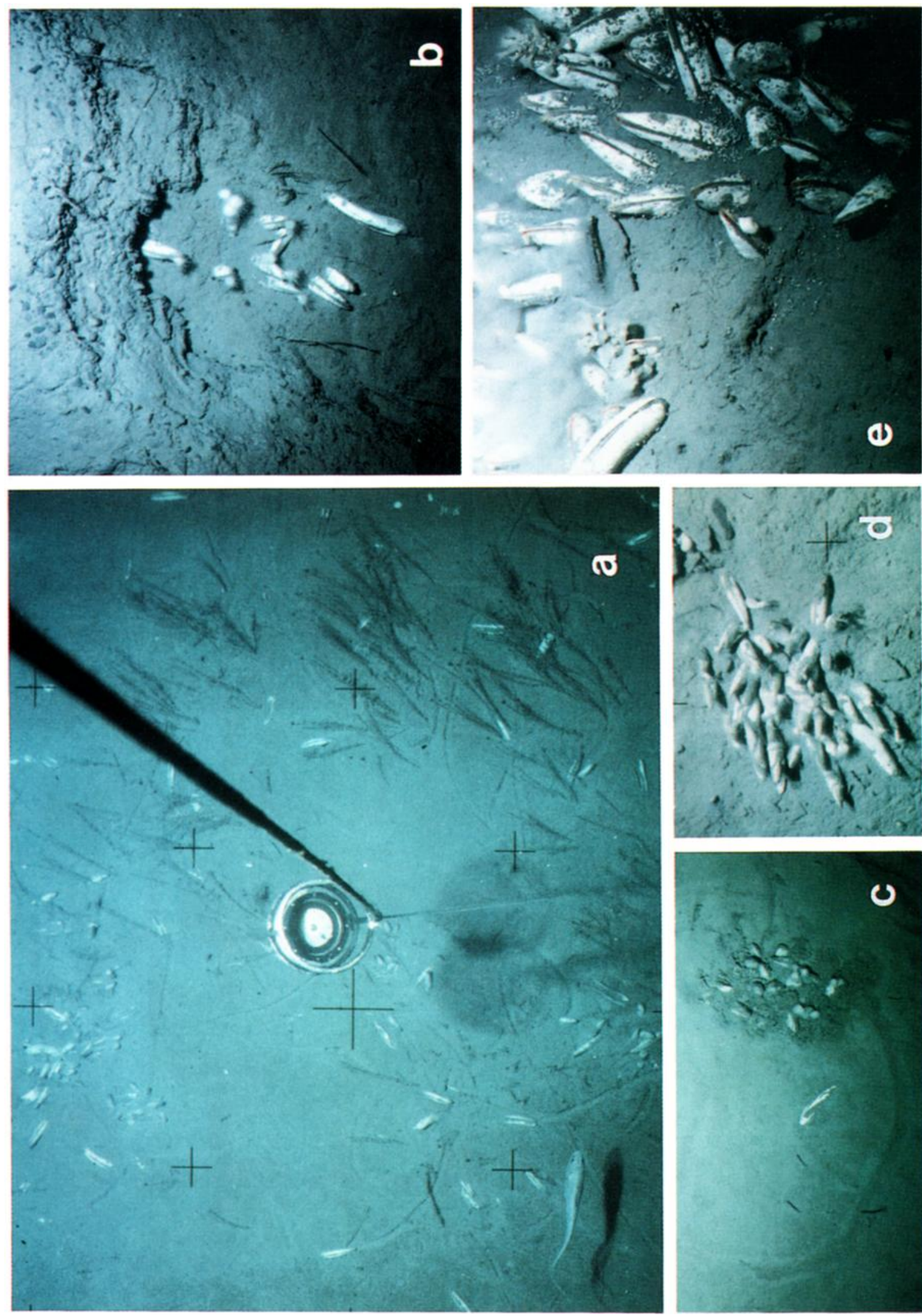
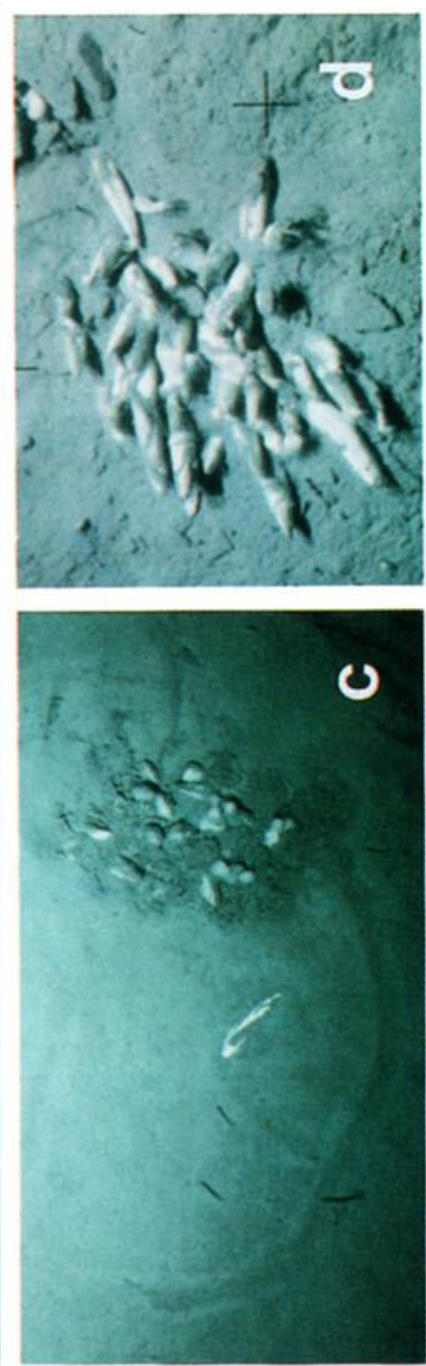

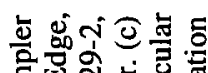

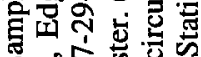

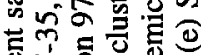
Ð5。영

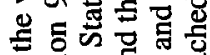

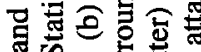

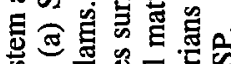

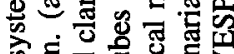
क

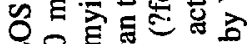

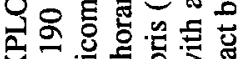
准言密

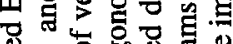

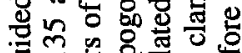

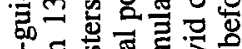

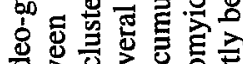

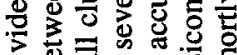
o 喝

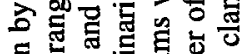
ए

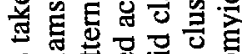
g 可.

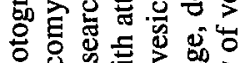
응.

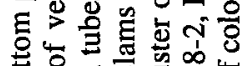
응 졍

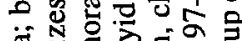

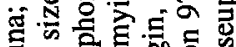

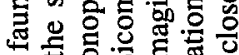
三

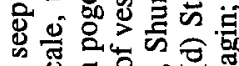
क्य Uं -

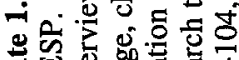

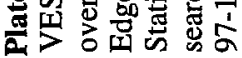



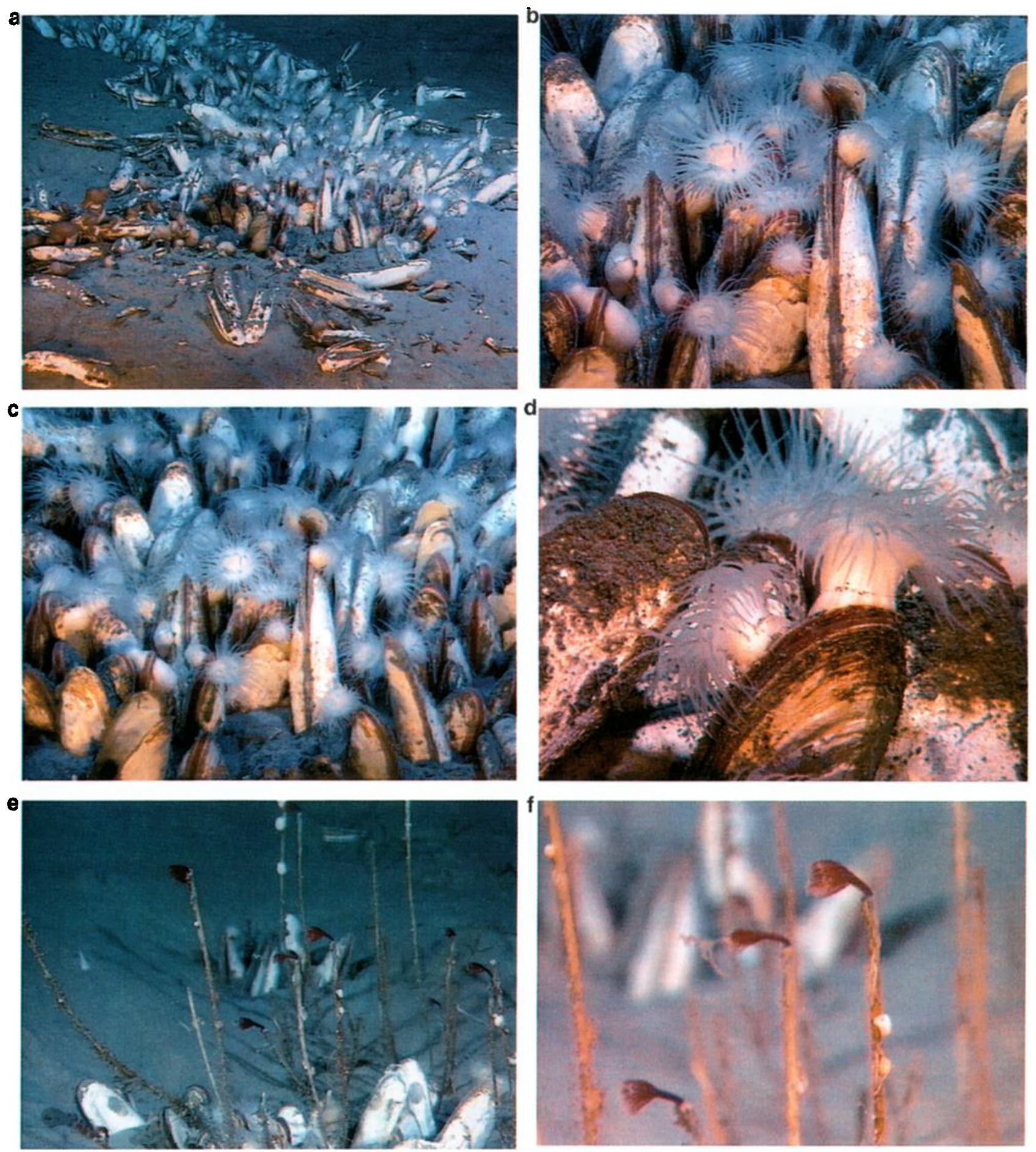

Plate 2. Cold seep fauna; bottom photographs taken by ROPOS-three-chip CCD camera system (station 110-23, Edge). For scale; the size of vesicomyid clams range between 135 and $190 \mathrm{~mm}$. (a) Alignment of cold seep communities. (b), (c), and (d) Extensive populations of vesicomyid clams (higher magnification of population seen in Plate 2a (c) and (f) Pogonophorans amongst clams and gastropods (Plate $2 \mathrm{f}$ has higher magnification of pogonophorans seen in (e) Plate 2e shows gastropod egg cases present on two pogonophoran tubes).

(stations 97-21 and 97-35) of these structures showed vent fields indicated by bivalve colonies just off the ridge crests on the trench-facing flank (Figure 2). Examples of the towed EXPLOS video documentation are shown in Plate 1 . The trenchward flank of the first deformation ridge during SO 110 also became the target of the longest and deepest ROPOS deployment ever (station
110-23 [Suess and Bohrmann, 1997; Orange et al., 1996]). The vehicle was equipped with two video cameras, a wide angle silicon intensified tube (SIT), low light camera, and a three-chip $\mathrm{CCD}$, broadcast quality color camera with $16 \mathrm{X}$ zoom. The video tapes were recorded in Beta $5 \mathrm{P}$ format for the vehicle's color camera and Super VHS for the vehicle's black and white camera. 
Extensive photo documentation was obtained by these systems, and selected views of communities are shown in Plate 2 [ Lutz et al., 1996]. The alignment of cold seeps is along geologic structures, as is their preferred location at the base of steps or in depressions. Extensive populations of vesicomyid clams, buccinid gastropods, and pogonophorans were documented [Lutz et al., 1996]. Analysis of ROPOS videos shows that the average clam field is $\sim 0.7 \mathrm{~m}^{2}$ in area [Sahling, 1997].

Attempts at sampling of colonies in the Edge sector using a TV-guided grab (sampling area $1.82 \mathrm{~m}^{2}$ ) at one station (station 97 66) yielded 119 specimens of vesicomyid clams and seven specimens of solemyids. At another station (station 97-22), 21 specimens of vesicomyid clams and 14 specimens of solemyids were collected from this same grab. Although the evaluation of the observed and sampled biota is far from complete, our preliminary assessment based on two surveys at each sector and the analysis of ROPOS videos show population densities at vent sites of between $159-200$ individuals $/ \mathrm{m}^{2}$. A total of over $56 \mathrm{~m}^{2}$ of active vents were documented with several thousand specimens of bivalves [Sahling, 1997].

The nutritional pathway at the vent ecosystems of the Aleutian Trench is also chemoautotrophic as previously observed in other subduction settings. The carbon isotopes of the soft tissues and of the chitinous hard parts exhibit $\delta^{13} \mathrm{C}$-enriched stable isotope patterns (Table 2). The $\delta^{13} \mathrm{C}$ values for all of the non calcareous parts analyzed range from $-28.6 \%$ to $-64.3 \%$ o Pee Dee belemnite (PDB) and thus show thiotrophic and methanotrophic portions of carbon incorporated. The values are similar to or exceed those reported from vent colonies of other subduction zones and are comparable to those from biota of other prominent cold seeps not related to subduction [e.g., Paull et al., 1992]. The $\delta^{13} \mathrm{C}$ enrichment of the pogonophoran tubes of the Shumagin sector $\left(\delta^{13} \mathrm{C}=-64.3 \%\right.$ PDB $)$ is the strongest observed so far.

Previous reports on $\delta^{13} \mathrm{C}$ of pogonophoran tubes are from the Cascadia margin [Kulm et al., 1986], the Florida Escarpment
[Paull et al., 1984], the Skagerrak [Schmaljohann et al., 1990], and the Louisiana slope [Brooks et al., 1987]. Only Siboglinum sp. from the Skagerrak appears to incorporate as large a portion of methane-derived carbon as the specimens from the Shumagin sector reported here. The tubes $\delta^{13} \mathrm{C}$ values of around $-65 \%$ PDB are close to the $\mathrm{C}$ isotope composition of a slightly depleted biogenic methane pool from the Cascadia subduction zone [Suess and Whiticar, 1989]. This value identifies methanotrophy as the dominant carbon metabolizing pathway. Pogonophorans from the Edge sector, tentatively identified as Lamellisabella sp. and Polybrachia sp., on the other hand, showed $\delta^{13} \mathrm{C}$ values from -40 to 47\%o PDB (Table 2), indicating thiotrophic carbon metabolism. A single vestimentiferan genus from the Edge sector analyzed so far is even less depleted in $\delta^{13} \mathrm{C}(-28.6 \%$ PDB), thereby supporting thiotrophy. The soft tissue parts separated from vesicomyid clam and solemyid specimens from the Edge sector have relatively "heavy" $\delta^{13} \mathrm{C}$ values of between -33 and $-40 \%$ PDB with slight enrichment in the gills (Table 2). These values indicate thiotrophic carbon metabolisms, whereby methane, via sulfate reduction, may provide the sulfide needed by the sulfur-oxidizing microbes.

The carbonate shell material also exhibits evidence for chemoautotrophic-derived carbon. Usually, shells of vent bivalves are only slightly enriched in $\delta^{13} \mathrm{C}$ because they preferentially incorporate bicarbonate from seawater, but for vesicomyid clams from the Cascadia subduction zone it was shown that the inner complex cross-lamellar layer is more enriched in $\delta^{13} \mathrm{C}$ than the outermost shell layer [Wagner, 1994]. Presumably, the close proximity of the shell-secreting mantle to the digestive system, where light metabolic carbon is generated and the inner shell layer formed, could retard dilution by seawater bicarbonate and hence preserve more lighter carbon. For solemyid shells, no such distinction between inner and outer shell layers was possible, although, in general, the bulk of their carbonate was isotopically lighter than the carbonate of vesicomyid clam shells from the Edge sector (Table 2). A value of $-7.9 \%$ PDB indicates that

Table 2. Stable Carbon Isotope Composition of Selected Tissue and Hard Parts of Vent Fauna

\begin{tabular}{|c|c|c|c|c|c|}
\hline Fauna & Station/Sector & Tissue Part & $\begin{array}{c}\delta^{13} \mathrm{C} \% o \\
\text { Maximum }\end{array}$ & $\begin{array}{c}\delta^{13} \mathrm{C} \% o \\
\text { Minimum }\end{array}$ & $\begin{array}{c}\delta^{13} \mathrm{C} \% o \\
\text { Mean }\end{array}$ \\
\hline Vesicomyid clam & 97-66/Edge & $\begin{array}{l}\text { mantel } \\
\text { gill } \\
\text { foot (inner) } \\
\text { foot (outer) } \\
\text { aductor close to } \\
\text { foot }\end{array}$ & $\begin{array}{l}-36.66 \\
-37.31 \\
-39.87 \\
-35.89 \\
-36.30\end{array}$ & $\begin{array}{l}-36.64 \\
-37.43 \\
-39.94 \\
-36.28 \\
-36.24\end{array}$ & $\begin{array}{l}-36.65 \pm 0.01 \\
-37.37 \pm 0.06 \\
-39.90 \pm 0.03 \\
-36.09 \pm 0.02 \\
-36.27 \pm 0.03\end{array}$ \\
\hline Solemyid specimen & 97-22/Edge & $\begin{array}{l}\text { periostracum } \\
\text { mantel } \\
\text { gill } \\
\text { siphon } \\
\text { shell } \\
\text { viscera }\end{array}$ & $\begin{array}{l}-30.22 \\
-34.06 \\
-35.29 \\
-33.43 \\
-8.09 \\
-34.12\end{array}$ & $\begin{array}{l}-29.09 \\
-34.04 \\
-35.40 \\
-33.29 \\
-7.80 \\
-34.16\end{array}$ & $\begin{array}{r}-29.60 \pm 0.5 \\
-34.05 \pm 0.01 \\
-35.35 \pm 0.05 \\
-33.36 \pm 0.06 \\
-7.90 \pm 0.10 \\
-34.14 \pm 0.02\end{array}$ \\
\hline $\begin{array}{l}\text { Pogonophoran } \\
\text { Lamellisabella ? }\end{array}$ & 97-22/Edge & $\begin{array}{l}\text { tube including } \\
\text { organism }\end{array}$ & -43.25 & -40.55 & $-41.9 \pm 0.1$ \\
\hline Polybrachia? & 97-22/Edge & $\begin{array}{l}\text { tube including } \\
\text { organism }\end{array}$ & -47.35 & -47.50 & $-47.4 \pm 0.1$ \\
\hline Vestimentiferan & 97-22/Edge & $\begin{array}{l}\text { tube including } \\
\text { organism }\end{array}$ & -28.80 & -28.43 & $-28.6 \pm 0.2$ \\
\hline Pogonophoran & 97-97/Shumagin & $\begin{array}{l}\text { empty tube, upper } \\
\text { empty tube, lower }\end{array}$ & $\begin{array}{l}-67.37 \\
-55.82\end{array}$ & $\begin{array}{l}-61.13 \\
-58.35\end{array}$ & $\begin{array}{l}-64 \pm 3 \\
-57 \pm 1\end{array}$ \\
\hline
\end{tabular}

$\delta^{13} \mathrm{C}, \%$ relative to Pee Dee belemnite (PDB). 
solemyids utilize a mixture of metabolic and bottom water $\mathrm{CO}_{2}$ in building their shells, probably because of their peculiar habit of living buried in the vent sediment and pumping bottom water through their burrows. Other vent organisms which showed a similar $\delta^{13} \mathrm{C}$-enriched bulk calcareous skeleton have been the serpulid worm tubes collected at the cold seeps of the Peru subduction zone [Wagner, 1994], the shells of Thyasira sp. from the Skagerrak (-12\%o PDB [Schmaljohann et al., 1990]) and mytilids from the Florida Escarpment (-8\%o PDB [Paull et al., 1985]).

\subsection{Precipitates}

Carbonate and barite crusts, cemented sediment, and chimneylike structures are typical precipitates which form around subduction vents and cold seeps [ Ritger et al., 1987; Kulm and Suess, 1990; Paull et al., 1992; Dia et al., 1993]. This precipitation results from excess carbonate generated by the anaerobic microbial oxidation of methane in the case of carbonate and from mixing of Ba-saturated vent fluid with $\mathrm{SO}_{4}$-rich bottom water in the case of barite [Ritger et al., 1987; Torres et al., 1996]. Aside from their variable composition and apparent disequilibrium mineral assemblages, vent carbonates are always enriched in $\delta^{13} \mathrm{C}$. Extreme stable isotope values of between -40 and $-70 \%$ PDB have been reported [Ritger et al. , 1987; Roberts and Aharon, 1994]. At both the Edge and the Shumagin sectors, carbonate and sulfate precipitates occur as a result of fluid venting. They range from disseminated microcrystalline phases to fragile linings of fluid channels to large, dense impermeable precipitates and crusts. Their presence in certain depth horizons is evident from the chemical composition of sediments, particularly when cores from on-vent locations are compared to those from off-vent locations. Most prominent are zones of vent-induced calcium carbonate and barite formation at station 97-66 in the Edge sector. At a depth between 5 and $35 \mathrm{~cm}$ below seafloor the $\mathrm{CaCO}_{3}$ content increases to almost $10 \mathrm{wt} \%$ from a level of usually no more than $1 \mathrm{wt} \%$ and the total $\mathrm{Ba}$ content from a background of $\sim 700 \mathrm{ppm}$ to almost $6000 \mathrm{ppm}$. The distribution of these precipitates downcore is discussed later in the context of pore water chemistry from their surrounding sediment, vent fluid composition, and flow rate estimates, but first we describe here the appearance of the precipitates, as diagnostic features for cold vents.

Scanning electron microscopic (SEM) images from the macroscopically identifiable precipitates of the $\mathrm{Mg}$ calcite and barite linings of open channels in sediments from the Edge sector (station 97-66), and from the carbonate crusts from Shumagin (station 97-97) are shown in Figure 6. The barium sulfate crystals are composed of a dense filling of fragile barite needles (Figure 6d) which show a palisade fabric (Figures 6a and 6c) and often a concentrically layered structure (Figure 6b) which represents several generations of precipitation. The dense carbonate crusts from the Shumagin sector appears under the SEM as a structureless cryptocrystalline matrix $<2-3 \mu \mathrm{m}$ that forms an intergranular cement. Euhedral Mg-calcite crystals (Figure 6f) were only found in larger pore space cavities such as in diatom frustules and radiolarian tests (Figures $6 \mathrm{e}$ and $6 \mathrm{~g}$ ). The mineralogy of both $\mathrm{Mg}$-calcite and barite was confirmed by $\mathrm{X}$ ray diffraction.

The carbon isotope signature $\left(\delta^{13} \mathrm{C}\right)$ of the Edge carbonates ranges from $-10.7 \%$ to $-14.3 \%$ and of the oxygen isotopes $\left(\delta^{18} \mathrm{O}\right)$ from $1.1 \%$ to $+2.9 \%$ PDB (Figure 7 ). The Shumagin precipitates are also calcitic but consist of cryptocrystalline subparallel layers which coalesce to form large aggregates. The carbon isotope composition is between -45.9 and $-50.8 \%$ PBD, in agreement with values of other vent carbonates worldwide. The oxygen isotope composition $\left(\delta^{18} \mathrm{O}=+2.1\right.$ to $\left.+3.2 \% \circ \pm 0.1 \% \circ \mathrm{PDB}\right)$ is significantly "lighter" than would be expected from equilibrium with the low bottom-water temperature and oceanic isotope composition. At present, it is not clear whether the "light" oxygen isotope values indicate formation at elevated temperatures or precipitation from fluids having a different $\delta^{18} \mathrm{O}$ makeup than present day seawater. The vent carbonates from Edge and Shumagin sectors differ in their $\delta^{13} \mathrm{C}$ values by approximately the same magnitude as do the tissues of the vent organisms from the two areas, except the range of values for tube worm from Edge is large. Since all specimens from Edge belong to different taxa, isotope fractionation during $\mathrm{C}$ incorporation into the tube worms seems likely, although different sources of nutritional carbon cannot be excluded.

\section{Fluids and Flow Rates}

Ever since the discovery of subduction vents, the magnitude of flow and the modulation of flow rates over time remain two of the most significant open questions. The flow rate is important for estimating fluid budgets and mass transport rates. It is a key parameter for modeling tectonic dewatering during subduction accretion and is considered of major importance in the buildup of mechanical stress which eventually may lead to earthquakes [Sammonds et al., 1992]. Combining direct flow measurements at active vent sites with sequential water sampling and highresolution pore water chemistry is our approach to quantify flow rates and chemically diagnose vent fluids.

A TV-guided instrument for vent fluid sampling (VESP) has been available for the in situ measurements of flow rates from vents, which is described in detail elsewhere [Linke et al., 1994; Carson et al., 1990]. This instrument, not unlike a benthic chamber, is towed close to the seafloor near active dewatering zones and placed over vent colonies when the track accidentally passes directly over an active vent. Precise active deployment is not possible as in the case of submersible or ROV operations. On average, six to eight attempts are needed for one successful VESP deployment by towing. Besides a thermistor flowmeter which is positioned in the channeled flow which emanates from the seafloor, the benthic chamber contains sequentially triggered water samplers which enable monitoring of the concentration changes of certain vent tracers with time. Methane, sulfide, oxygen, ${ }^{4} \mathrm{He}, \mathrm{Ba}$, and $\mathrm{Li}$ have been successfully used as tracers [Linke et al., 1994; Torres et al., 1996]. A typical deployment time at present is between 30 and $60 \mathrm{~min}$. Modifications of the instrument are underway to extend on-bottom time considerably by decoupling the system from the surface vessel after deployment and utilizing a free-return mode of the instrument when the sampling and measuring cycle is completed.

The VESP instrument, when deployed sufficiently long over a vigorously flowing vent, samples a mixture of vent fluid and ambient bottom water. Once vent fluid tracers have been identified, their flux rate into the bottom chamber of the VESP instrument can be used to derive the water flow. Likewise, the oxygen demand of a vent ecosystem may, under certain assumptions, also yield vent fluid flow [Wallmann et al., 1997b]. These estimates may then be compared to directly measured rates by the VESP flow meter, as previously shown by Carson et al. [1990] and Linke et al. [1994] and to geophysically derived rates [von Huene et al., 1997].

\subsection{Direct Flow Measurements}

VESP deployments at the eastern Aleutian subduction zone yielded results close to the detection limit of the thermistor flow 


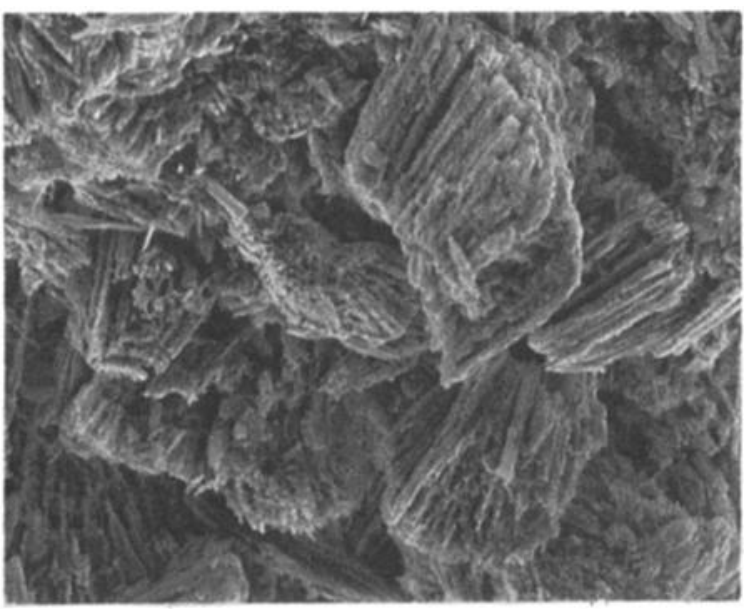

a

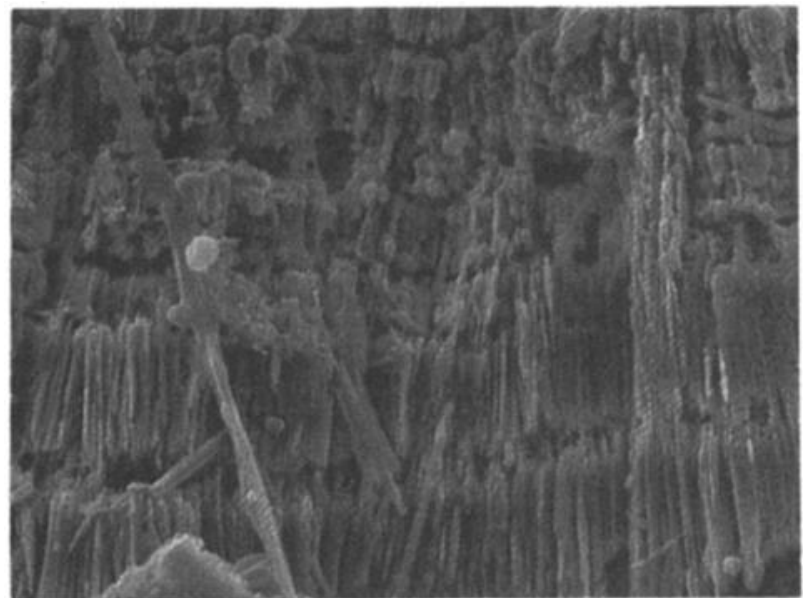

C

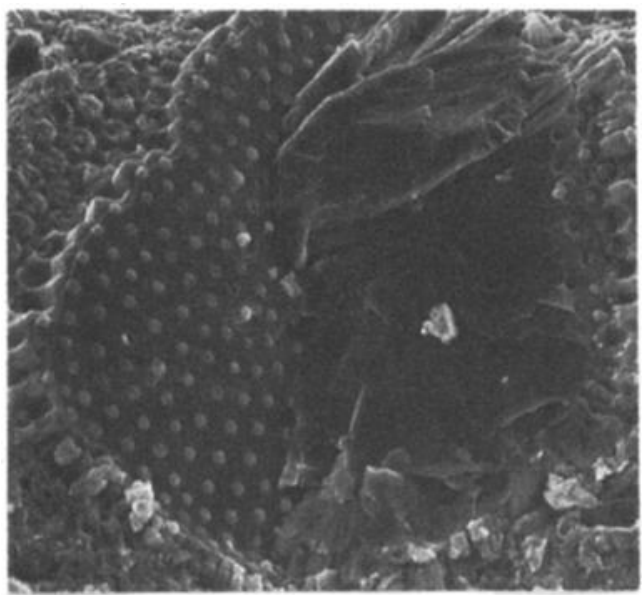

$\mathbf{e}$

Figure 6. Scanning electron photomicrographs (SEM) of barite precipitates as fragile linings in fluid channels from sediments of the Edge sector; station 97-66 (Figures 6a, 6b, 6c, and 6d) and of carbonate cemented sediments from station 97-79 (Figures 6e, 6f, and 6g). Mineralogy by energy dispersive (EDS) and X ray diffraction (XRD) analyses. Scale bar for Figures $6 \mathrm{a}$ and $6 \mathrm{e}$ is $30 \mu \mathrm{m}$; (scale bar for Figures $6 \mathrm{~b}, 6 \mathrm{c}, 6 \mathrm{~d}$, 6f, and 6g is $10 \mu \mathrm{m}$.

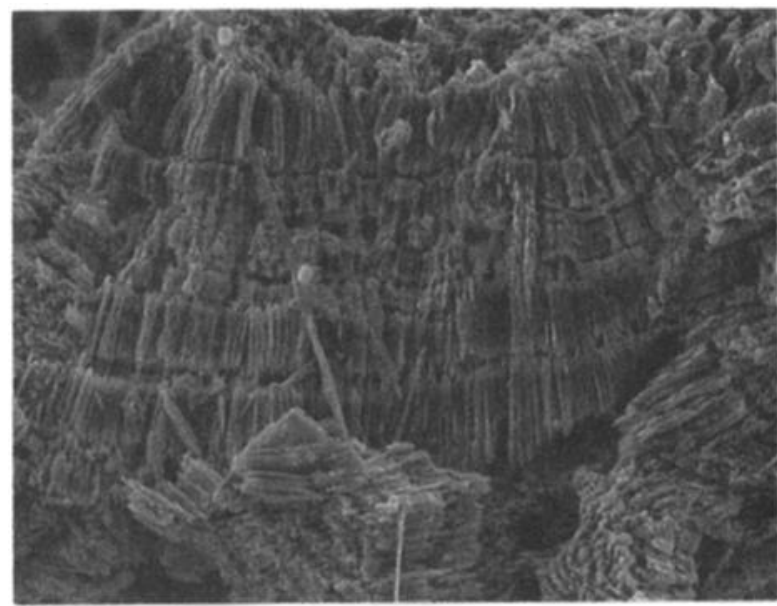

b

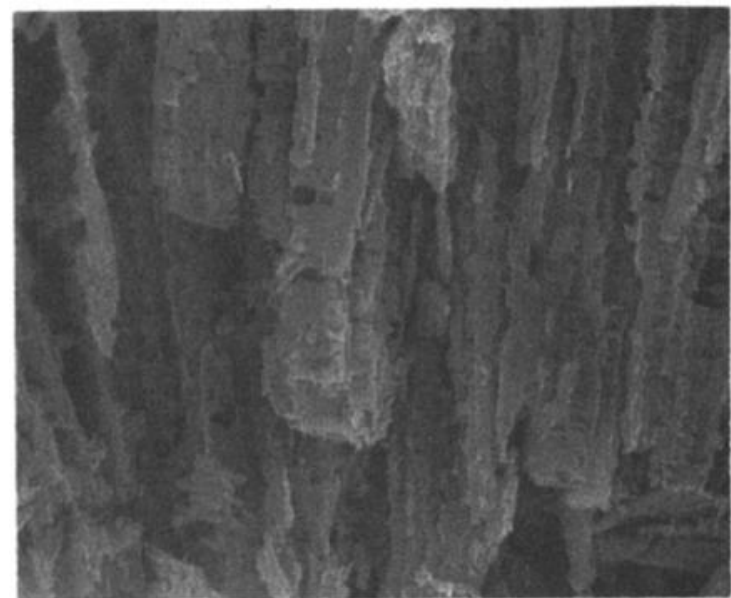

d

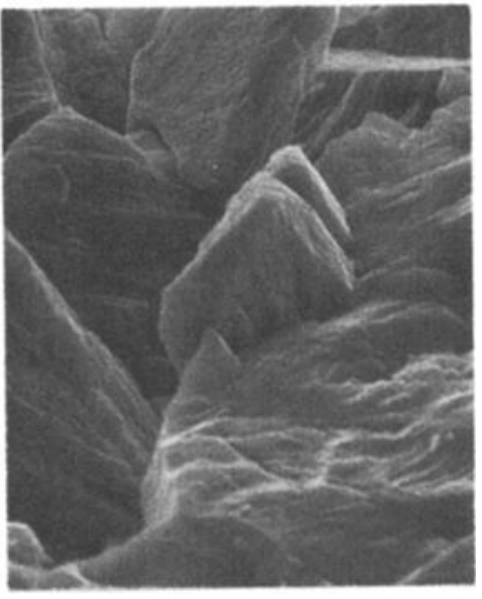

f

g

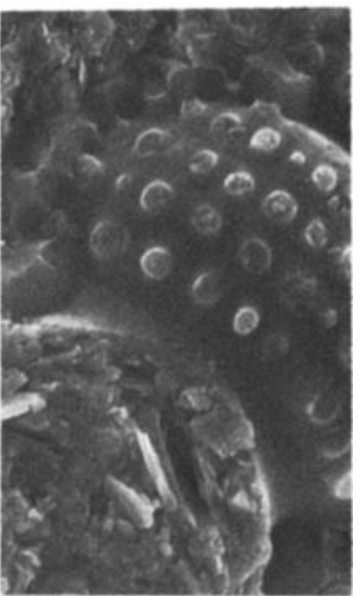

- 


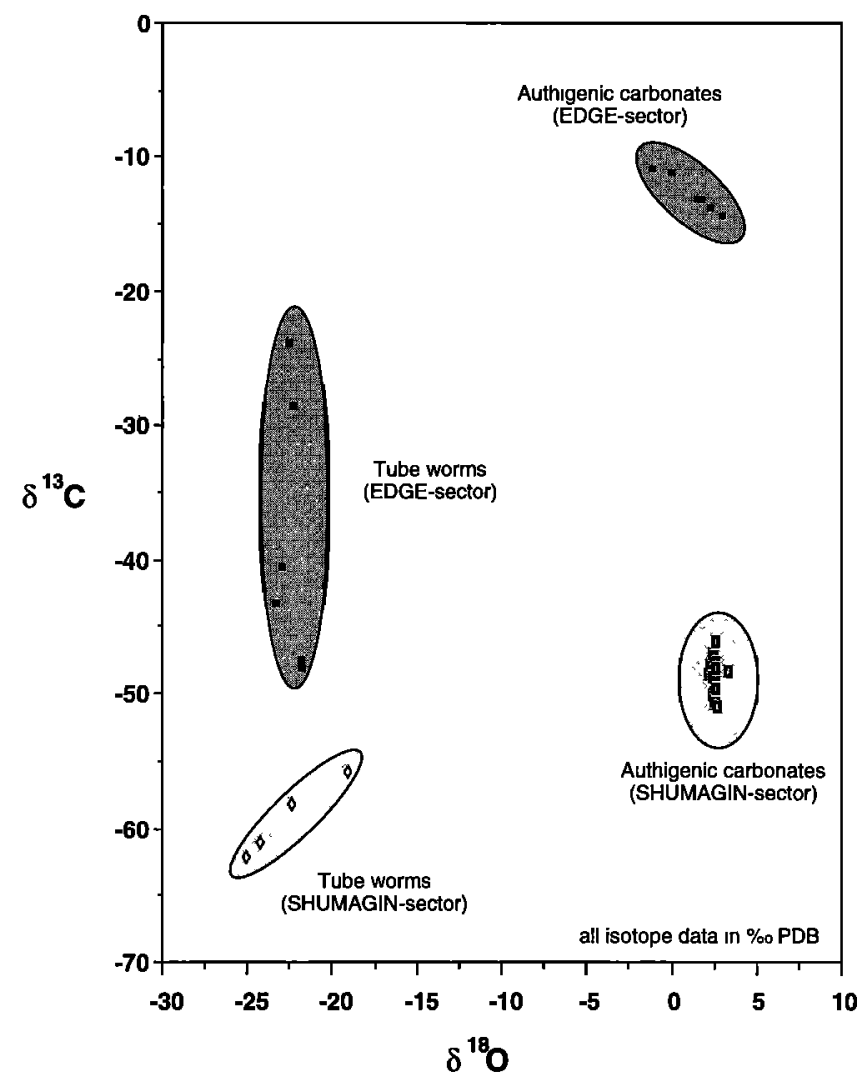

Figure 7. Comparison of stable carbon versus oxygen isotopes from vent carbonates and pogonophoran tubes between the Edge and Shumagin sectors. Consistently lighter $\mathrm{C}$ isotopes at Shumagin might indicate methylotrophic, and heavier $\mathrm{C}$ isotopes at Edge might indicate thiotrophic vent metabolism.

meter. In the Shumagin sector (station 97-104), we recorded directly a water outflow of $10 \pm 8 \mathrm{~L} \mathrm{~m}^{-2} \mathrm{~d}^{-1}\left(=240 \pm 200 \mathrm{~L} \mathrm{~m}^{-2} \mathrm{~d}^{-1}\right)$ averaged over short deployment periods of up to $40 \mathrm{~min}$. This value falls into the lower range of previous measurements off Oregon and Peru where between 500-1700 $\mathrm{L} \mathrm{m}^{-2} \mathrm{~d}^{-1}$ were recorded, although the margin of error is rather high for the Aleutian Trench data.

\subsection{Biogeochemical Approach}

In the Edge area the thermistor measurements produced no reliable results due to very slow flow rates. Nevertheless, the water samples recovered during four successful VESP deployments allowed the quantification of fluid flow based on a biogeochemical approach. A steady decrease in dissolved oxygen with time was observed at vent sites and used to calculate an average oxygen consumption rate of $3.3 \pm 0.4 \mathrm{mmol} \mathrm{m}^{-2} \mathrm{~h}^{-1}$. The rate is 2 orders of magnitude higher than the benthic oxygen flux at deep-sea locations not influenced by fluid venting [Wallmann et $a l ., 1997 \mathrm{~b}$. It is caused by the oxidation of reduced inorganic compounds transported to the vent site by the tectonically driven fluid flow. Using the contents of methane $(0.3 \mathrm{mmol})$, sulfide (4 $\mathrm{mmol}$ ), and ammonia ( $3 \mathrm{mmol}$ ) in vent fluids of core 97-66 from the Edge area, the average fluid discharge at vent sites was calculated to be $0.23 \mathrm{~L} \mathrm{~m}^{-2} \mathrm{~d}^{-1}$ [Wallmann et al., 1997b]. The vent fluid composition used is that represented by the highest metabolite concentrations in pore fluids from on-vent site 97-66 (Figures 8a-81).

\subsection{Fluid Composition and Mixing}

The pore fluids, especially those from the heavily sedimented vents as in the Edge sector, represent a mixture of vent fluid, diagenetic pore water and to a considerable degree ambient bottom water. The latter is pumped and recirculated into the vent system by benthic biota [Wallmann et al., 1997b]. The endmember composition of the pristine vent fluid and the diagenetic pore water cannot, at present, be exactly differentiated, but the contrast between the concentration-depth profiles from on-vent and off-vent locations identifies the dominant fluid transport modes and the environment in which diagenetic precipitates form. The most dramatic differences in pore water chemistry and solid phase composition between on-vent and off-vent sites are shown in Figures 8a-81 and briefly summarized here for the Edge sector based on data from stations 97-66 and 97-72. A more detailed discussion of these data is given by Wallmann et al. [1997b]: (1) Methane is virtually absent in the sediments from the off-vent site but high at the on-vent site (Figure 8c). Owing to the lack of sufficient closely spaced samples, the profile is a composite of sediments from stations 97-66 and 97-22. The low methane content of two off-vent cores is shown as well (stations 97-72 and 97-88). (2) Calcium carbonate and barite precipitates form distinct layers in the on-vent sediment (Figures $8 \mathrm{a}$ and $8 \mathrm{~b}$ ). It appears that the $\mathrm{CaCO}_{3}$ layer is located at depth (maximum at $32 \mathrm{~cm}$ below seafloor (bsf) with two barite layers above (maximum at $16 \mathrm{~cm}$ bsf and $8 \mathrm{~cm} \mathrm{bsf}$ ). The process controlling formation of these precipitates is not subject of this paper; (3) however, the pore water data on dissolved calcium (Figure 81), barium (Figure 8k), and $\Sigma \mathrm{CO}_{2}$ along with the $\delta^{13} \mathrm{C}$ of $\Sigma \mathrm{CO}_{2}$ (Figure 8i) clearly document a relationship between diagenetic environment and mineral formation. (4) On the basis of their dissolved $\mathrm{Cl}$ (Figure 8d) the pore waters from both sites are indistinguishable. (5) The on-vent site lacks a nitrate-containing suboxic layer (Figure 8e). (6) Very low sulfate contents, high sulfide concentrations (Figure $8 \mathrm{~h}$ ), and very high ammonia concentrations (Figure $8 \mathrm{~g}$ ) characterize the on-vent sediments. These early diagenetic metabolites and methane are oxidized and consumed in or near the sediment surface by the vent megafauna and the energy released during these redox reactions is used by the benthic organisms for growth and metabolism.

The shape of several dissolved constituents of the on-vent pore water profiles indicates that the topmost $25 \mathrm{~cm}$ are influenced by the mixing of vent fluid with bottom water via bioirrigation. The irregular distribution and elevated $\mathrm{NO}_{2}$ contents (Figure $8 \mathrm{f}$ ) attests to pumping activity. The peculiarly depleted $\mathrm{SiO}_{2}$ concentrations in the on-vent sediment (Figure $8 \mathrm{j}$ ) is due to the same process. Because dissolved silicate is not consumed by organisms it may serve as a tracer for fluid mixing [Wallmann et al., 1997b]. Bioirrigation manifests itself at site 97-66 in lower concentrations of silica and elevated $\mathrm{NO}_{2}$ contents. The benthic megafauna pumps bottom water with low $\mathrm{SiO}_{2}$ content and some free oxygen into the vent system, thereby diluting the diagenetic pore water. Using a transport reaction model, bioirrigation was identified as the dominant transport mode at vent sites in the Edge area [Wallmann et al., 1997b] The bivalves at vent sites pump water through their bodies and through the surrounding sediments at a rate that is several orders of magnitude higher than the tectonically driven fluid flow. Taking the abundance of Solemya $s p$. and Calytogena sp. at the vent sites, it may be estimated that the 

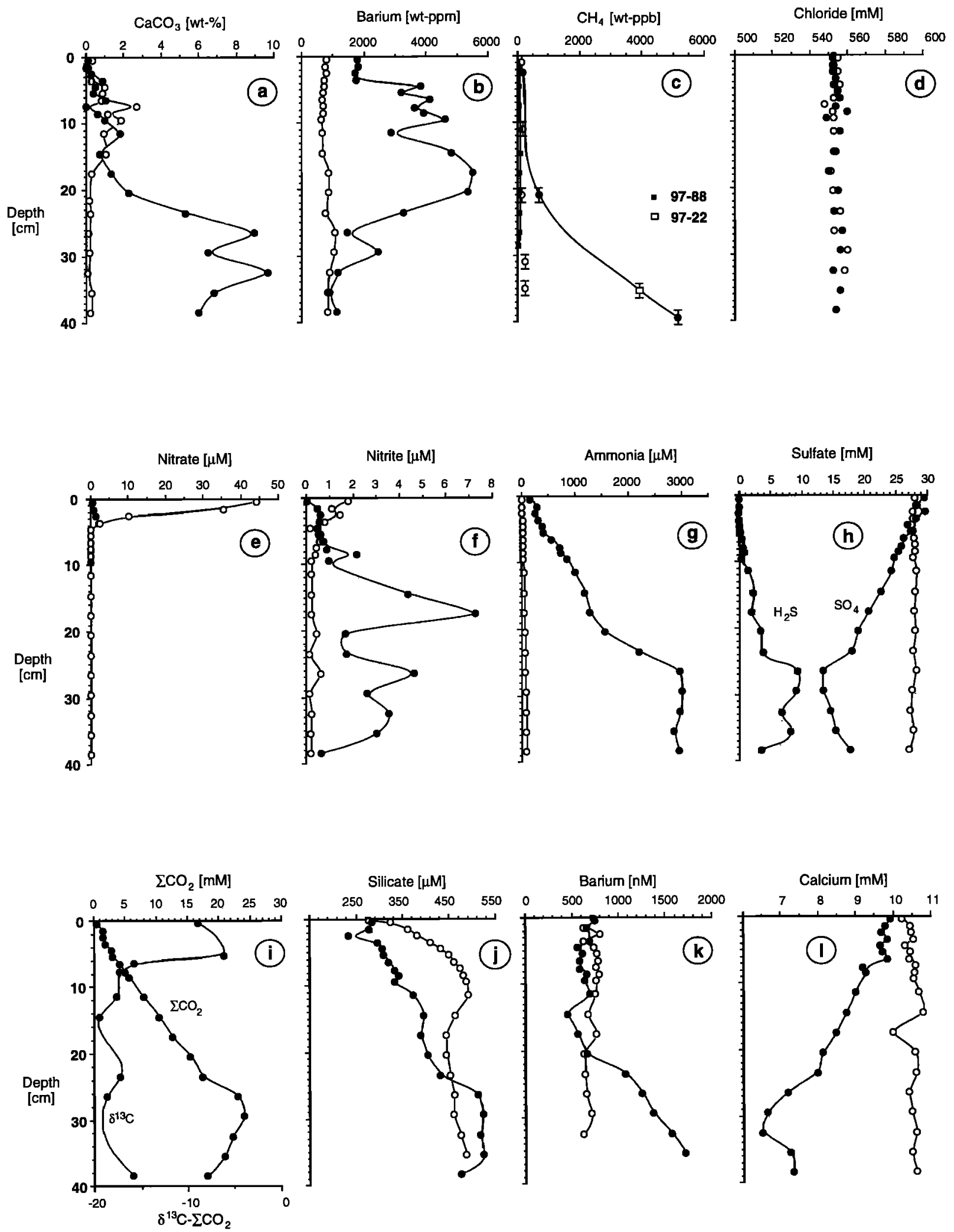

Figure 8. Comparison of sediment composition and pore water chemistry between on-vent (station 97-66, solid symbols) and off-vent (station 97-72, open symbols) locations at Edge sector (see location map of Figure 2). The on-vent characteristics are (a) $\mathrm{CaCO}_{3}$ and (b) $\mathrm{Ba}$ in layers; (c) high $\mathrm{CH}_{4}$; (d) normal oceanic $\mathrm{Cl}$; (e) lack of $\mathrm{NO}_{3}$ containing suboxic layer; (f) unexpectedly high $\mathrm{NO}_{2}$; (g) very high $\mathrm{NH}_{4}$; (h) low $\mathrm{SO}_{4}$ and very high $\mathrm{H}_{2} \mathrm{~S}$; (i) high $\Sigma \mathrm{CO}_{2}$ and very significantly depleted $\delta^{13} \mathrm{C}$ of $\Sigma \mathrm{CO}_{2}$ (on-vent location only); (j) peculiarly depleted $\mathrm{SiO}_{2}$ contents; (k) high dissolved $\mathrm{Ba}$, and (l) low dissolved $\mathrm{Ca}$. 
biological pumping rate is close to $100 \mathrm{~L} \mathrm{~m}^{-2} \mathrm{~d}^{-1}$ whereas the tectonically induced fluid flow amounts to only $0.2 \mathrm{~L} \mathrm{~m}^{-2} \mathrm{~d}^{-1}$.

\section{Discussion}

The importance of these considerations for the deep-sea environment depends on the reliability of large-scale regional and eventual global extrapolation to the world's subduction zones. Geophysical approaches have in the past been the only attempt at estimating subduction-generated fluid return fluxes. The discrepancy among these estimates, based essentially on gross porosity reduction from seismic velocity analyses, and the directly measured flow rates have been pointed out repeatedly. Up to now there has been no compelling idea put forward on how to reconcile these order-of-magnitude differences. In the context of our investigation we can now, for the first time, make a reliable comparison of both approaches. Frühn [1995] and von Huene et al. [1997] have derived a detailed porosity reduction for the Edge sector based on combined reflection and refraction velocity analyses for sediment deformed during the last $500 \mathrm{kyr}$ (Figure 9). This shows that the initial dewatering during formation of the first and second ridges was associated with up to $50 \%$ of the total net fluid loss occurring principaily across a $5.5 \mathrm{~km}$ wide zone adjacent to the deformation front. The highest rates of dewatering and tectonic shortening occur as imbricate structures develop adjacent to the deformation front and sediment becomes consolidated sedimentary rock. Thereafter porosity reduction is relatively slow and involves deeper sedimentary units.

During our R/V Sonne surveys the areas of the first and second deformation ridges were imaged by the EXPLOS video and by ROPOS camera surveys. The segment corresponds to $\mathrm{km} 7$ to $12.5 \mathrm{~km}$ on the reconstructed fluid loss profile (Figure 9) by von Huene et al. [1997]. Over this distance of $5.5 \mathrm{~km}, 36.5 \%$ of the total fluid loss occurs which translates into a mean dewatering rate of $0.02 \mathrm{~L} \mathrm{~m}^{-2} \mathrm{~d}^{-1}$ or $8.6 \mathrm{~L} \mathrm{~m}^{-2} \mathrm{~d}^{-1}$. Our survey clearly revealed that a minimum of $0.1 \%$ of the segment between $\mathrm{km} 7.0$ and $\mathrm{km} 12.5$ showed venting [Sahling, 1997]. Hence an average rate of $20 \mathrm{~L} \mathrm{~m}^{-}$ ${ }^{2} d^{-1}$ per active vent is expected based on the geophysical estimate. This is in surprisingly good agreement with the biogeochemically derived rate of $5.5 \pm 0.5 \mathrm{~L} \mathrm{~m}^{-2} \mathrm{~d}^{-1}$. The large biological pumping rate at vent sites may bias the thermistor flow measurements and the determination of fluid flow rates from biogeochemical and temperature gradients in surface sediments. We feel that the previous discrepancies in reported flow rates may be partially caused by this effect.

\section{Conclusion}

Along the Aleutian subduction zone, fluid venting was directly observed along an $800 \mathrm{~km}$ long segment of its deep-sea trench off Alaska. Geophysical anomalies associated with venting here are observed an additional $250 \mathrm{~km}$ toward the northeast. The cold seep sites are concentrated at the initial ridges associated with the deformation front and are controlled by structure. The characteristics of cold seeps seen at other convergent margins are all documented along the lowermost, seaward facing slope of the Aleutian Trench. These characteristics include (1) methane plumes in the lower water column; (2) plume maxima which are traceable to deformation ridges and structural settings associated with vents; (3) evidence for a small temperature anomaly at the cold seep sites; (4) prolific colonies of vent biota aligned and distributed in patches controlled by fault scarps oversteepened folds or bedding exposed by mass wasting; (5) calcium carbonate and barite precipitates at the surface and subsurface of cold vents; and (6) carbon isotope evidence from tissue and skeletal hard parts of biota, as well as from carbonate precipitates, that vents expel either methane- or sulfide-dominated fluids. This difference in chemistry might be related to age and source depth of fluids; they may have migrated from great depth along vertical shear faults in
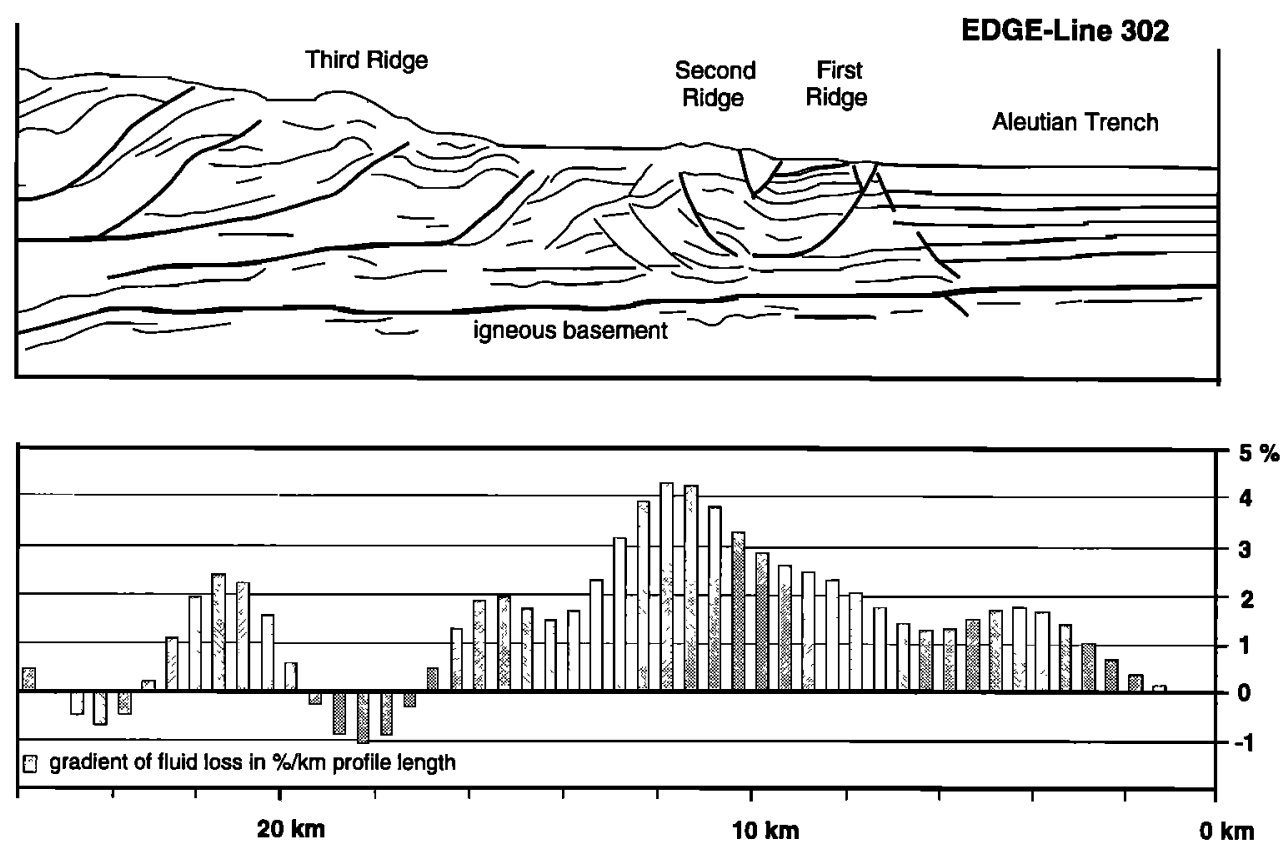

Figure 9. Structure of accretionary complex in the Edge sector; line drawing from the SW part of line 302 . Fluid loss in percent of total dewatering per kilometer profile length and $1.8 \mathrm{My}$ of convergence age; fluid loss is calculated from porosity reduction and convergence reconstruction [modified from Frühn, 1995; von Huene et al., 1997]. 
the Shumagin sector. A biogeochemical approach toward estimating fluid flow rates based on oxygen consumption and fluid chemistry at vent sites in the Edge sector converges towards a mean value of $5.5 \pm 0.5 \mathrm{~L} \mathrm{~m}^{-2} \mathrm{~d}^{-1}$ for tectonics-induced water flow.

Acknowledgments. We greatly appreciate the support, cooperation, and professionalism at sea of masters $\mathrm{H}$. Papenhagen and $\mathrm{J}$. Wagener and the crew of R/V Sonne during the cruises SO-96, SO-97, and SO-110. We thank B. Domeyer, A. Bleyer, T. Schott, M. Schumann, F. Appel, and A. Cremer for continued excellent technical support; and A. Dahlmann, J. Greinert, N. Maher, E. Zuleger, G. Rehder, N. von Mirbach, G. Levai, and C. Moyer for their enthusiasm and indispensable help at sea during cruise SO-110. A few preliminary data are included here from their work to support our earlier findings. Special thanks go to Tim Shank (Rutgers University) for preparing and making available the illustrations of Plate 2. We also thank G. Fischer (University of Bremen) for the $\delta^{13} \mathrm{C}$ measurements on organic matter and shell material of the vent fauna. The comments by J. Martin, University of Florida, and an anonymous reviewer are most gratefully acknowledged. Financial support for the investigations using R/V Sonne was provided by the Federal Ministry of Education, Research and Technology, Bonn (grants 03G0096A, 03G0097A, and 03G0110A/B). The National Science Foundation, Washington, made funds available through grants OCE-93-02205 and OCE-96-33131 to R. Vrijenhoek and R. Lutz, Rutgers University, to help support the ROPOS deployment during SO-110.

\section{References}

Barry, J.P., H.G. Green, D.L. Orange, C.H. Baxter, B.H. Robison, R.E. Kochevar, J.W. Nybakken, D.L. Reed, and C.M. McHugh, Biologic and geologic characteristics of cold seeps in Monterey Bay, California, Deep Sea Res. I, 43 (11-12), 1739-1762, 1996.

Boulègue, J., E.L. Benedetti, D. Dron, A. Mariotti, and R. Létolle, Geochemical and biogeochemical observations on the biological communities associated with fluid venting in Nankai Trough and Japan Trench subduction zones, Earth Planet. Sc. Lett., 83, 343-355, 1987.

Brooks, J. M., M. C. Kennicutt II, C. R. Fisher, S. A. Macko, K. Cole, J. J. Childress, R. R. Bidigare, and R. D. Vetter, Deep-sea hydrothermal seep communities: Evidence for energy and nutritional carbon sources, Science, 238, 1138-1141, 1987.

Brown, K.M., B. Bekins, B. Clennell, D. Dewhurst, and G. Westbrook, Heterogeneous hydrofracture development and accretionary fault dynamics, Geology, 22, 259-262, 1994.

Bruns, T.R., Model for the origin of the Yakutat Block, an accreting terrane in the northern Gulf of Alaska, Geology, 11,718-721, 1983.

Carson, B., E. Suess, and J.C. Strasser, Fluid flow and mass flux determinations at vent sites on the Cascadia Margin accretionary prism, J. Geophys. Res., 95(B6), 8891-8897, 1990.

Carson, B., E. Seke, V. Paskevich, and M.L. Holmes, Fluid expulsion sites on the Cascadia accretionary prism: Mapping diagenetic deposits with processed GLORIA imagery, J. Geophys. Res., 99(B6), 11,959$11,969,1994$.

Childress, J.J., C.R. Fisher, J.M. Brooks, M.C. Kennicutt II, R.R. Bidigare, and A.E. Anderson, A methanotrophic marine molluscan (Bivalvia, Mytilidae) symbiosis: Mussels fueled by gas, Science, 233, 1306$1308,1986$.

Davis, E.E., R.D. Hyndman, and H. Villinger, Rates of fluid expulsion across the Northern Cascadia accretionary prism: Constraints from new heat flow and multichannel seismic reflection data, $J$. Geophys. Res., 95(B6), 8869-8889, 1990.

de Angelis, M.A., and C. Lee, Methane production during zooplankton grazing on marine phytoplankton, Limnol. Oceanogr. 39(6), 12981308, 1994.

DeMets, C., R.G. Gordon, D.F. Argus, and S. Stein, Current plate motions, Geophys. J. Int., 101, 425-478, 1990.

Dia, A.N., L. Aquilina, J. Boulèque, J. Bourgois, E. Suess, and M. Torres, Origin of fluids and related barite deposits at vent sites along the Peru convergent margin, Geology, 21, 1099-1102, 1993.

Embley, R.E., et al., Geological setting of chemosynthetic communities in the Monterey Fan Valley system, Deep Sea Res., 37(11), 1651-1667, 1990.

Felbeck, H., J.J. Childress, and G.N. Somero, Calvin-Benson cycle and sulphide oxidation enzymes in animals from sulphide-rich habitats, Nature, 293, 291-293, 1981.
Fiala-Médioni, A., and M. LePennec, Adaptive features of the bivalve molluscs associated with fluid venting in the subduction zones off Japan, Palaeogeogr. Palaeoclimatol. Palaeoecol., 71, 161-168, 1989.

F1ala-Médioni, A., J. Boulègue, S. Ohta, H. Felbeck, and A. Mariotti, Source of energy sustaining the Calyptogena populations from the deep trenches in subduction zones off Japan, Deep Sea Res., 40, 1241$1258,1993$.

Flüh, E., and R. von Huene, FS Sonne Cruise 96 KODIAK SEIS, KodiakHong Kong, Fahrtbericht 210pp., GEOMAR Forschungs-zentrum fur marine Geowissenschaften der Christian-Albrechts-Universität Kiel, Germany, 1994.

Frühn, J., Tektonik und Entwaesserung des aktiven Kontinentalrandes suedoestlich der Kenai-Halbinsel, Alaska, GEOMAR Rep. 39, 93pp., GEOMAR Forschungszentrum fur marine Geowissenschaften der Christian-Albrechts-Universitat Kiel, Germany, 1995.

Hashimoto, J., S Ohta, T. Tanaka, H. Hotta, S. Matsuzawa, and H. Sakai, Deep-sea communities dominated by the giant clam, Calyptogena soyoae, along the slope foot of Hatsushima Island, Sagami Bay, central Japan, Palaeogeogr. Palaeoclimatol. Palaeoecol. 71, 179-192, 1989

Henry, P., J -P. Foucher, X. Le Pichon, M. Sibuet, K. Kobayashi, P. Tarits, N Chamot-Rooke, T. Furuta, and P. Schultheiss, Interpretation of temperature measurements from the Kaiko-Nankai cruise: Modeling of fluid flow in clam colonies, Earth Planet. Sc. Lett., 109, 355-371, 1992.

Henry, P., X. Le Pichon, S. Lallemant, S. Lance, J. Martin, J.-P. Foucher, A. Fiala-Médioni, F. Rostek, N. Guilhaumou, V. Pranal, and M. Castrec, Fluid flow in and around a mud volcano field seaward of the Barbados accretionary wedge: Results from Manon cruise, $J$. Geophys. Res., 101(B8), 20,297-20,313, 1996.

Horibe, Y., K.-R. Kim, and H. Craig, Hydrothermal methane plumes in the Mariana back-arc spreading centre, Nature, 324, 131-133, 1986.

Hyndman, R.D., K. Wang, T. Yuan, and G.D. Spence, Tectonic sediment thickening, fluid expulsion, and the thermal regime of subduction zone accretionary prisms: The Cascadia margin off Vancouver Island, $J$. Geophys. Res., 98(B 12), 21,865-21,876, 1993

Kastner, M., H. Elderfield, and J.B. Martin, Fluids in convergent margins: What do we know about their composition, origin, role in diagenesis and importance for oceanic chemical fluxes, Philos. Trans. R. Soc. London A, 335, 243-259, 1991.

Kulm, L.D. and E. Suess, Relationship between carbonate deposits and fluid venting: Oregon accretionary prism. J. Geophys. Res., 95 (B6), 8899-8915, 1990.

Kulm, L. D., and R. von Huene, Initial Reports of the Deep Sea Drilling Project, vol. 18., U.S. Govt. Print. Off., Washington, D. C., 1973.

Kulm, L.D., et al., Oregon subduction zone: Venting, fauna, and carbonates, Science, 231, 561-566, 1986.

Lammers, S., E. Suess, and M. Hovland, A large methane plume east of Bear Island (Barents Sea): Implications for the marine methane cycle, Geol. Rundsch., 84, 59-66, 1995.

Langseth, M G., and J. C. Moore, Introduction to special section on the role of fluids in sediment accretion, deformation, diagenesis, and metamorphism in subduction zones, J. Geophys. Res., 95(B6), 8737$8741,1990$.

Le Pichon, X., et. al., Nankai Trough and Zenisu Ridge: A deep-sea submersible survey. Earth Planet. Sci. Lett., 83, 285-299, 1987.

Le Pichon, X., P. Henry, and S. Lallement, Water flow in the Barbados accretionary complex, J. Geophys. Res., 95(B6), 8945-8967, 1990.

Lewis, S.D., J.W. Ladd, and T.R. Bruns, Structural development of an accretionary prism by thrust and strike-slip faulting: Shumagin region, Aleutian Trench., Geol. Soc. Am. Bull., 100, 767-782, 1988.

Lilley, M.D., D.A. Butterfield, E.J. Olson, J.E. Lupton, S.A. Macko, and R.E. McDuff, Anomalous $\mathrm{CH}_{4}$ and $\mathrm{NH}_{4}$ concentrations at an unsedimented mid-ocean ridge hydrothermal system, Nature, 364, 4547, 1993.

Linke, P., E. Suess, M. Torres, V. Martens, W.D. Rugh, W. Ziebis, and L.D. Kulm, In situ measurement of fluid flow from cold seeps at active continental margins, Deep Sea Res., 41, 721-739, 1994.

Lutz, R., et al., Biological communities and geological features associated with methane/sulfide seepage at $4960 \mathrm{~m}$ in the Aleutian subduction zone, EosTrans. AGU 77(46), Fall Meet. Suppl., F405, 1996.

Martın, J.B., M. Kastner, and H. Elderfield, Lithium: sources in pore fluids of Peru slope sediments and implications for oceanic fluxes, Mar. Geol., 102, 281-292, 1991.

Martin, J.B., M. Kastner, and P. K. Egeberg, Origins of saline fluids at convergent margins, in Active Margins and Marginal basins of the 
western Pacific, Geophys. Monogr. Ser., vol. 88, edited by B. Taylor, pp. 219-239, AGU Washington, D. C., 1995.

Martin, J.B., M.M. Kastner, P. Henry, X. Le Pichon, and S. Lallemant, Chemical and isotopic evidence for sources of fluids in a mud volcano field seaward of Barbados accretionary wedge, J. Geophys. Res., 101(B8) 20,325-20,345, 1996.

McAdoo, B.G., E.A. Silver, D. Orange, K.D. McIntosh, L. Kahn, L. Abbott, J. Galewsky, and M. Protti, Seafloor structural observations from Costa Rica accretionary prism, Geophys. Res. Lett. 23(8), 883886, 1996.

Moore, C.J., et al., EDGE deep seismic reflection transect of the eastern Aleutian arc-trench layered lower crust reveals underplating and continental growth, Geology, 19, 420-424, 1991.

Moore, J.C., and P. Vrolijk, Fluids in accretionary prisms, Rev. Geophys., 30, 113-135, 1992.

Ohta, S., and L. Laubier, Deep biological communities in the subduction zone off Japan from bottom photographs during Nautile dives in the KAIKO project, Earth Planet. Sci. Lett., 83, 329-342, 1987

Olu, K., A. Duperret, M. Sibuet, J.-P. Foucher, and A. Fiala-Médion1, Structure and distribution of cold-seep communities along the Peruvian active margin: Relationship to geological and fluid patterns, Mar. Ecol. Progress Ser., 132, 109-125, 1996.

Orange, D., et al., Fluid seepage at the toe of the Aleutian accretionary complex: Observations from the longest and deepest ROPOS dive yet, Eos Trans. AGU, 77(46), Fall Meet. Suppl., F 323, 1996.

Paull, C.K., B. Hecker, B. Commeau, R.P. Freeman-Lyndre, A.C. Neumann, W.P. Corso, S. Golubic, J. Hook, E. Sikes, and J. Curray, Biological communities at Florida Escarpment resemble hydrothermal vent communities, Science, 226, 965-967, 1984.

Paull, C.K., A.J.T. Jull, L.J. Toolin, and T. Linick, Stable isotope evidence for chemosynthetic in an abyssal seep community, Nature, 317, 709$711,1985$.

Paull, C.K., J.P. Chanton, A.C. Neumann, J.A. Coston, and C.S. Martens, Indicators of methane-derived carbonates and chemosynthetic organic carbon deposits: Examples from the Florida Escarpment, Palaios, 7, 361-375, 1992.

Radlinski, A.P., and Z. Leyk, Formation of light-hydrocarbon anomalies in oceanic waters, Geology, 23, 265-268, 1995.

Rau, G H., C. M. McHugh, C. Harrold, C Baxter, B. Hecker, and R.W. Embley, $\delta^{13} \mathrm{C}, \delta^{15} \mathrm{~N}$, and $\delta^{18} \mathrm{O}$ of Calyptogena phaseoliformis (bivalve mollusc) from the Ascension Fan-Valley near Monterey, California, Deep Sea Res., 37, 1669-1676, 1990.

Rio, M., M. Roux, M. Renard, and E. Schein, Chemical and isotopic features of present day bivalve shells from hydrothermal vents or cold seeps, Palaios, 7351-360, 1992

Ritger, S., B. Carson, and E. Suess, Methane-derived authigenic carbonates formed by subduction-induced pore-water expulsion along the Oregon/Washington margin, Geol. Soc. Am. Bull., 98, 147-156, 1987.

Roberts, H.H., and P. Aharon, Hydrocarbon-derived carbonate buildups of the northern Gulf of Mexico, Geo Mar. Lett., 14, 135-148, 1994.

Sahling, H., Untersuchungen an cold seep assoziierten Organismen im NEPazifik, Diplomarbeit, 96 pp., Univ. of Kiel, Kiel, Germany, 1997.

Sammonds, P.R., P.G. Meredith, and I.G. Main, Role of pore fluids in the generation of seismic precursors to shear fracture, Nature, 359, 228$230,1992$.

Schmaljohann, R., E. Faber, M.J. Whiticar, and P.R. Dando, Co-existence of methane- and sulfur-based endosymbioses between bacteria and invertebrates at a site in the Skagerrak, Mar. Ecol. Prog. Ser., 61, $119-$ 124,1990

Scranton, M. I., and P. G. Brewer, Consumption of dissolved methane in the deep ocean, Limnol. Oceanogr. 23(6), 1207-1213, 1978.

Sibuet, M., S.K. Juniper, and G. Pautot, Cold-seep benthic communities in the Japan subduction zones: Geological control of community development, J. Mar. Res., 46, 333-348, 1988.

Southward, A.J., E.C. Southward, P.R. Dando, G.H. Rau, H. Felbeck, and $\mathrm{H}$. Flügel, Bacterial symbionts and $l o w{ }^{13} \mathrm{C} /{ }^{12} \mathrm{C}$ ratios in tissues of Pogonophora indicate unusual nutrition and metabolism, Nature, 293, 616-620, 1981

Southward, A.J., E.C. Southward, P.R. Dando, R. L. Barett, and R. Ling, Chemoauthotrophic function of bacterial symbionts in small pogonophora, J. Mar. Biol Assoc. U.K. 66, 415-437, 1986.

Stevenson, A.J., and R. Embley, Deep-sea fan bodies, terrigenous turbidite sedimentation, and petroleum geology, Gulf of Alaska, in Geology and Resource Potential of the Continental Margin of Western North America and Adjacent Ocean Basins-Beaufort Sea to Baja California Earth Sci. Ser., vol. 6, edited by D.W. Scholl, A. Grantz, and J.G. Vedder, pp. 503-522, Circum-Pac. Counc. for Energy and Miner. Resour., Houston, Tex., 1987.

Suess, E., FS Sonne Fahrtbericht SO 97 KODIAK-VENT, GEOMAR Rep. 29 , p. 220, GEOMAR Forschungszentrum für marine Geowissenschaften der Christian-Albrechts-Universität Kiel, Germany 1994.

Suess, E. and G. Bohrmann, FS Sonne Fahrtbericht SO 110 SO-RO GEOMAR Rep. 59, 181, GEOMAR Forschungszentrum für marine Geowissenschaften, Christian-Albrechts-Universität Kiel, Germany, 1997.

Suess, E., and M.J. Whiticar, Methane-derived $\mathrm{CO}_{2}$ in pore fluids expelled from the Oregon subduction zone, Palaeogeogr. Palaeoclimatol. Palaeoecol., 71, 119-136, 1989.

Suess, E., B. Carson, S.D. Ritger, J.C. Moore, M.L. Jones, L.D. Kulm, and G.R. Cochrane, Biological communities at vent sites along the subduction zone off Oregon, Biol. Soc. Wash. Bull., 6, 475-484, 1985.

Tilbrook, B.D., and D. M. Karl, Methane sources, distributions and sinks from California coastal waters to the oligotrophic North Pacific gyre, Mar. Chem., 49, 51-64, 1995.

Torres, M., G. Bohrmann, E. Suess, J. Boulege, and J. Bourgois, Authigenic barites and fluxes of barium associated with fluid seeps in the Peru subduction zone, Earth Planet. Sci. Lett., 144, 469-481, 1996.

von Huene, R., Continental margins around the Gulf of Alaska, in The Eastern Pactfic Ocean and Hawaii, edited by E.L. Winterer, D.M. Hussong, and R.W. Decker, pp. 383-401, Geol. Soc. of Am., Boulder, Colo., 1989.

von Huene, R., and D. Scholl, Observations at convergent margins concerning sediment subduction, subduction erosion and the growth of continental crust, Rev. Geophys., 29, 279-316, 1991.

von Huene, R., and D. M. Scholl, The return of sialic material of the mantle indicated by terrigeneous material subducted at convergent margins, Tectonophysics, vol. 219, pp. 163-175, 1993.

von Huene, R., M.A. Fisher, and T.R. Bruns, Geology and evolution of the Kodiak margin, Gulf of Alaska, in Geology and Potential of the Continental Margin of Western North America and Adjacent Ocean Basins-Beaufort Sea to Baja California, Earth Sci Ser., vol. 6, Circum-Pac. Counc. for Energy and Miner. Resour., edited by D.W. Scholl, A. Grantz, and J.G. Vedder, pp. 191-212, Houston, Tex., 1987.

von Huene, R., D. Klaeschen, M. Gutscher, and J. Frühn, Mass and fluid flux during accretion at the Alaska margin, Geol. Soc. Am. Bull., in press, 1997.

Wagner, C., Cold Seeps an konvergenten Plattenrändern vor Oregon und Peru: Biogechemische Bestandsaufnahme, GEOMAR Rep. 53, 108pp., GEOMAR Forschungszentrum für marine Geowissenschaften der Christian-Albrechts-Universität Kiel, Germany, 1997.

Wallmann, K., E. Suess, G.H. Westbrook, G. Winckler, M.B. Cita, and MEDRIFF Consortium, Salty brines on the Mediterranean floor, Nature, 387, 31-32, 1997a.

Wallmann, K., et. al., Quantifying fluid flow, solute mixing, and biogeochemical turnover at cold vents of the eastern Aleutian subduction zone, Geochim. Cosmochim. Acta, in press 1997b.

Westbrook, G.K., B. Carson, R.T. Musgrave, and E. Suess (Eds.) Proceedings of the Ocean Drilling Program, Scientific. Results, 146; Ocean Drill. Program, College Station, Tex., 1995.

G. Bohrmann, S. Lammers, P. Linke, H. Sahling, E. Suess, R. von Huene, and $\mathrm{K}$. Wallmann, GEOMAR, Research Center for Marine Geosciences, Wischhofstr. 1-3, D-24148 Kiel, Germany. (e-mail: gbohrmann@geomar.de; slammers@geomar.de; plinke@geomar.de; esuess@geomar.de; rhuene @inforum.net; kwallmann@geomar.de)

R. A. Lutz, Centre for Deep-Sea Ecology and Biotechnology, Institute of Marine and Coastal Sciences, Rutgers University, New Brunswick, 08903 NJ. (e-mail: rlutz@zodiac.rutgers.edu)

D. Orange, Monterey Bay Aquarium Research Institute, 7700 Sandholdt Rd., Moss Landing, CA 95039. (e-mail:dano@mbari.org)

G. Winckler, Institut für Umweltphysik de r Unıversität Heidelberg, Im Neuenheimer Feld 366, D-69120 Heidelberg, Germany. (e-mail: WI@uphys l.uphys.uni-heidelberg.de)

(Received February 6, 1997; revised July 16, 1997; accepted July 23, 1997.) 